\title{
REPRESENTAÇÕES SOCIAIS SOBRE 'SER PROFESSOR DE FÍSICA' À LUZ DO MODELO KVP
}

ADRIANO JOSÉ ORTIZ ${ }^{1}$

ORCID: https://orcid.org/0000-0002-2222-2603

CARLOS ALBERTO DE OLIVEIRA MAGALHÃES JÚNIOR² ORCID: https://orcid.org/0000-0002-1116-0777

ÉDER RODRIGO GIMENES ${ }^{3}$

ORCID: https://orcid.org/0000-0002-2059-186X

\begin{abstract}
RESUMO: Nesse artigo partimos dos referenciais de Conhecimentos, Valores e Práticas para identificar concepções e representações sociais em licenciandos em Física. Utilizamos 81 assertivas estruturadas de acordo com a escala likert. Esse instrumento foi aplicado com 25 ingressantes e 10 concluintes do curso. As respostas foram divididas em 19 indicadores previamente construídos e organizadas em três dimensões: 'epistemologia da ciência'; 'ensino e aprendizagem' e 'formação e atividade docente'. No caso dos ingressantes, os alunos apresentaram concepções contraditórias que podem refletir seus saberes e representações prévias ao ingressar no curso. Entre os concluintes, foi possível identificar algumas diferenças nas concepções. Ainda assim, essas diferenças foram progressivas, sem rompimentos abruptos com representações apresentadas pelos ingressantes. Enfim, nossos resultados indicam que um modelo de formação tradicional, em que os conhecimentos pedagógicos e didáticos são inseridos apenas posteriormente no curso, e não ao longo de todo ele, não proporciona um ambiente propício a mudanças profundas nessas representações.
\end{abstract}

Palavras-chave: concepções; formação de professores; alunos ingressantes; alunos concluintes; Física.

\section{SOCIAL REPRESENTATIONS ABOUT ‘BEING PHYSICS TEACHER’ BASED ON KVP MODEL}

\begin{abstract}
In this paper we start from the references of Knowledge, Values and Practices to identify conceptions and social representations in Physics undergratuates. We have used 81 propositions structured according to the likert scale. This instrument was applied with 25 begginers students and 10 graduates of the course. The answers were divided into 19 previous indicators and organized in three dimensions: 'epistemology of science'; 'Teaching and learning' and 'training and teaching activity'. In the case of the begginers, the students present contradictory conceptions that may reflect their knowledge and previous representations upon joining the course. Among the graduates, it was possible to identify

\footnotetext{
${ }^{1}$ Instituto Federal do Paraná (IFPR), campus Ivaiporã. Ivaiporã, PR, Brasil. <adriano.ortiz@ifpr.edu.br>

${ }^{2}$ Universidade Estadual de Maringá (UEM), Programa de pós graduação em Educação para a Ciência e Matemática. Grupo de Pesquisa em Ensino de Ciências, Formação de Professores e Representações Sociais - CIENCIAR. Maringá, PR, Brasil. <juniormagalhaes@hotmail.com> <ergimenes@uem.br>
}

3 Universidade Estadual de Maringá (UEM), Programa de pós graduação em Ciências Sociais. Maringá, PR, Brasil.
\end{abstract}


some differences in conceptions. Still, these differences were progressive, without abrupt breaks with representations presented by the begginers. Finally, our results indicate that a traditional training model, in which pedagogical and didactic knowledge is inserted only later in the course, and not throughout it does not provide an environment conducive to profound changes in these representations.

Keywords: conceptions; teacher training; begginers students; concluding students; Physics.

\section{REPRESENTACIONES SOCIALES SOBRE "SER UN PROFESOR DE FÍSICA" A LA LUZ DEL MODELO KVP}

RESUMEN: En este artículo partimos de los referenciales de Conocimientos, Valores y Prácticas para identificar concepciones y representaciones sociales en licenciandos en Física. Utilizamos 81 afirmaciones estructuradas de acuerdo con la escala Likert. Este instrumento fue aplicado con 25 ingresantes y 10 concluyentes del curso. Las respuestas se dividieron en 19 indicadores previamente construidos y organizados en tres dimensiones: "la epistemología de la ciência"; "la enseñanza y el aprendizaje" y la "formación y la actividad docente". En el caso de los ingresantes, los alumnos presentaron concepciones contradictorias que pueden reflejar sus saberes y representaciones previas al ingresar al curso. Entre los concluyentes, fue posible identificar algunas diferencias en las concepciones. Aún así, estas diferencias fueron progresivas, sin rupturas bruscas con representaciones presentadas por los ingresantes. Finalmente, nuestros resultados indican que un modelo de formación tradicional, en el que los conocimientos pedagógicos y didácticos se insertan sólo posteriormente en el curso, y no a lo largo de todo él, no proporciona un ambiente propicio a cambios profundos en esas representaciones.

Palabras clave: concepciones; formación de profesores; alumnos ingresantes; alumnos finalizantes; Física.

\section{INTRODUÇÃO}

Apesar de diferentes paradigmas, propostas teóricas e metodológicas, algo que podemos evidenciar em pesquisas que tratam do Ensino de Física é que ser professor não é uma simples questão de 'bom senso'. Em outras palavras, não basta dominar o conhecimento científico e possuir carisma para estabelecer um ambiente propício à aprendizagem. Entretanto, Vasconcelos (2012) alerta para um contingente excessivo de indivíduos exercendo a docência na Educação Básica sem nenhum preparo para tal. Dessa forma, pensar a respeito dos professores que estamos formando se faz urgente, em um contexto em que problemas educacionais são tratados de maneira arbitrária pelo governo e decisões são tomadas de forma verticalizada, sem pensar nos impactos causados no trabalho daqueles que precisarão trazer para prática tais decisões.

Dentro de um paradigma emergente para a educação, Behrens (2013) descreve o professor como articulador, crítico e mediador do processo pedagógico. Não há espaço para estrelismos nesse caso, e o docente reduz gradativamente o espaço para aulas teóricas, enquanto estimula a busca por informações e o envolvimento dos alunos.

Nesse contexto, emerge uma nova área do conhecimento, a didática das Ciências, que destaca a importância do conteúdo no processo de aprendizagem e rejeita a ideia de que existem leis gerais de aprendizagem aplicáveis em qualquer ambiente (CACHAPUZ, 2001).

É perceptível que a atuação docente exige complexidade em relação ao que ensinar, e em como ensinar. Um corpo de conhecimentos e práticas se faz necessário para o trabalho do professor, envolve conhecer o conteúdo, métodos e práticas pedagógicas, o contexto de atuação, os alunos, além de ser capaz de desenvolver novos conhecimentos e exercer de forma ética sua função, bem como sua cidadania (SHULMAN, 1986; 1987; VASCONCELOS, 2012). A busca desse perfil docente passa por uma formação inicial que não pode ser resumida à justaposição de um bacharelado e um currículo didático pedagógico (CARVALHO, GIL-PÉREZ, 2011).

Não podemos, por uma questão dimensional e também de prudência, versar sobre a grande gama de elementos que pode influenciar em um processo de formação docente potencialmente 
significativo. Por isso, nesse trabalho nos concentramos em um dos elementos que pode contribuir com esse processo, as Representações Sociais (RS).

As Representações Sociais (RS) são elementos presentes no seio da sociedade e influenciam nosso comportamento bem como nossas perspectivas e decisões perante a comunidade em que vivemos. Elas orientam nossas ações e agem como um instrumento de leitura da realidade, como "teorias" do senso comum (MOSCOVICI, 2015).

O licenciando apresenta conhecimentos e experiências prévias que podem influenciar e dificultar sua formação docente (SALAZAR, 2005; ZAINKO, 2010). Apesar de alguns autores optarem por denominar esses conhecimentos como "concepções", eles podem ser compreendidos também como representações sociais (GALVÃO; MAGALHÃES JÚNIOR; CARVALHO, 2015).

As RS estão presentes na sociedade e influenciam nossos comportamentos, perspectivas e tomadas de decisões (JODELET, 2004; ALVES-MAZZOTTI, 2008; MOSCOVICI, 2015). Sua construção apresenta aspectos coletivos e individuais, e elas são prescritivas e convencionais, formando o que Moscovici (2015) denomina universo consensual. Nesse sentido, podemos entendê-las como teorias do senso comum.

De acordo com Moscovici (2015), dois processos compõem a construção de uma RS: a ancoragem e a objetivação. O primeiro coloca ideias estranhas em um contexto familiar, reduzindo-as à categorias e imagens comuns. Já o segundo processo relaciona a não familiaridade e a realidade, transformando um conceito em uma imagem.

Essas RS muitas vezes se tornam obstáculos na formação docente, dado que sua resistência às mudanças pode criar um ambiente desfavorável para construção de novos conhecimentos, como indicam os trabalhos de Hilger e Moreira (2016) e Ortiz e Magalhães Júnior (2018).

Ortiz e Magalhães Júnior (2018) chamam atenção para relações existentes entre RS e processos de aprendizagem. Para os autores, as semelhanças entre o conhecimento na perspectiva da aprendizagem significativa, bem como das representações sociais, se dão no âmbito do seu papel e do seu processo de construção. Dessa forma, é necessário compreender esses processos e seus elementos em comum para desenvolver uma discussão a respeito da construção de conhecimentos científicos ao longo da formação docente.

Em trabalho recente (ORTIZ; MAGALHÃES JÚNIOR, 2019), os autores investigaram o núcleo central e as periferias de RS de ingressantes e concluintes de uma licenciatura em Física. Por meio de uma abordagem estruturalista (ABRIC, 2000), concluíram que há uma elevada semelhança entre os núcleos de representação desses dois grupos, o que indica que se houve mudanças ao longo de sua formação, elas foram reversíveis ou progressivas.

No contexto de trazer novos elementos para a discussão dessa questão, construímos nosso problema de pesquisa, que, considerando os processos de construção de uma representação social, busca uma possível resposta para a questão: quais conhecimentos, valores e práticas a respeito da ciência e do ensino de ciências se mostram presentes em graduandos ao ingressarem e ao concluírem um curso de licenciatura em Física.

\section{OS CONHECIMENTOS, VALORES E PRÁTICAS (KVP) E AS REPRESENTAÇÕES SOCIAIS}

As RS, como propostas por Moscovici (2015), são ao mesmo tempo fruto da nossa própria vivência assim como daquilo que vivenciamos em comum com os outros. Em outras palavras, os universos do saber interno e externo ao indivíduo se complementam.

As representações têm como objetivo tornar algo não familiar em familiar. Conforme afirmamos anteriormente, dois processos descrevem como isso acontece, a ancoragem e a objetivação. $\mathrm{Na}$ ancoragem classificamos e damos nomes às coisas, enquanto a objetivação torna o objeto compreensível em si. Um exemplo de ancoragem é o modelo atômico planetário. Analisamos algo desconhecido (átomo) e relacionamos a algo conhecido (sistema solar) para compreendê-lo. Já no caso da objetivação, podemos pensar no conceito quântico de spin que é codificado como "giro" para ser compreendido. 
As representações sociais e as concepções a respeito de uma temática podem ser analisadas de várias maneiras. Uma delas é o modelo Conhecimentos (K - Knowledge), Valores (V) e Práticas (P), proposto por Clément (2004; 2006; 2010). Em seu trabalho de 2010, o autor defende que o senso comum pode ser entendido em sua dimensão individual, construída por nós ao longo da vida para a compreensão do que nos rodeia, e em sua dimensão coletiva, que é composta por interpretações compartilhadas por várias pessoas.

Algumas dessas interpretações são dominantes para alguns grupos, se caracterizando como representações sociais. Clément (2010) define que concepções se tratam de "coerências identificadas pelo pesquisador a partir de respostas de uma pessoa colocada em várias situações relativas à um determinado tema" (CLÉMENT, 2010, p.57, tradução dos autores). Já as RS, tratam-se de concepções coletivas, "coerências identificadas pelo pesquisador a partir de concepções individuais sobre o mesmo tema, identificadas em várias pessoas (grupo social)" (CLÉMENT, 2010, p.57, tradução dos autores).

Para o autor, essas concepções interagem em três polos, nos quais $\mathrm{K}$ representa os conhecimentos científicos, que apesar de referenciados nos trabalhos de cientistas, podem apresentar variações entre diferentes indivíduos. Essas variações são consequências da relação do conhecimento com os outros dois polos, os valores e as práticas.

O conhecimento torna possível assimilar, reter ou remodelar o que é útil para a prática do indivíduo $(\mathrm{P})$, enquanto a atenção e a importância dada ao conhecimento são provenientes em parte da interação entre o mesmo e o sistema de valores do sujeito (V) (CLÉMENT, 2004). Uma consequência dessa análise, apontada em outro de seus trabalhos (CLÉMENT, 2006), é que o conhecimento científico não é automaticamente definido como verdadeiro.

$\mathrm{Na}$ perspectiva do Ensino de Ciências, podemos compreender esses conceitos da seguinte maneira: Os conhecimentos $(\mathrm{K})$ são as concepções provenientes da comunidade científica, ou seja, os conhecimentos científicos; os valores $(\mathrm{V})$ se referem a crenças, ideologias, opiniões, tendo como exemplo dentro da Ciência, tendências epistemológicas como o reducionismo, construtivismo ou o realismo; já as Práticas $(\mathrm{P})$ tratam de práticas sociais, atuais ou futuras, sejam elas de pesquisa, ensino, aprendizagem ou do cotidiano (CLÉMENT, 2006; CARVALHO; CLÉMENT, 2007).

[...] a formação docente não pode restringir sua visão a respeito dos sujeitos desse processo entre aqueles que "sabem o conteúdo, mas não tem didática" e aqueles que "tem uma boa didática, mas não dominam o conteúdo", ou ainda, aqueles que "não possuem vocação para a docência (ORTIZ; MAGALHÃES JÚNIOR, 2018, p.40).

Os conhecimentos, valores e práticas relacionados ao ensino de ciências então se voltam para ambas as áreas, de forma a se complementarem e possibilitarem a construção de uma base de conhecimentos que dê significado à prática docente. Pensando nisso, buscamos elementos que caracterizem cada um desses conceitos no contexto do ensino de Física.

Primeiramente, é necessário compreender que o conhecimento não se restringe apenas aos conceitos físicos já construídos. Eles envolvem compreender os problemas que originaram esses conceitos, a forma como esses saberes são construídos, a forma como os cientistas tratam os problemas, as interações entre ciência, tecnologia e sociedade, a construção de uma visão dinâmica do conhecimento científico e a relação desses saberes com temas de outras áreas do conhecimento (GIL PÉREZ; VILCHES, 2004; CARVALHO; GIL-PÉREZ, 2011).

No que se refere ao ensino, nos fundamentando em trabalhos de Shulman $(1986 ; 1987)$ e autores que deram continuidade à sua proposta, compreendemos que o conhecimento docente se compõe, além do conhecimento do conteúdo, por conhecimentos pedagógicos, do aluno e do contexto. Essa interpretação é reforçada por autores que analisam questões do Ensino de Ciências a luz de uma didática específica (CACHAPUZ et al., 2001; GARCÍA-CARMONA, 2009; CARVALHO; GILPÉREZ, 2011).

É possível perceber o papel do Valores na construção do conhecimento ao considerarmos que a não linearidade e a gama de elementos que se inter-relacionam a caracteriza como um sistema 
complexo. Em outras palavras, a construção de conceitos e valores depende do encadeamento de relações entre componentes ou indivíduos que produzem o sistema (POOLE, 1995).

Como exemplo desses conceitos e valores, podemos identificar algumas das diferentes interpretações a respeito da construção do conhecimento científico (GIERE; 1988; POOLE, 1995; ROSENBERG, 2000):

- Positivismo: apresenta a necessidade de verificação com base nas sensações, de forma que a humanidade só pode saber aquilo que a ciência é capaz de descobrir;

- Empirismo: pressupõe que a experiência, ou observação, proveem a fundação de todo conhecimento científico;

- Realismo crítico: o que desenvolvemos são construções que tentam representar a natureza e se aproximam bastante desse intuito, porém, não são "a natureza em si";

- Instrumentalismo: teorias científicas são instrumentos úteis, de forma que a discussão a respeito de serem falsas ou verdadeiras não são relevantes;

- Estrutura das revoluções científicas (Kuhn): o conhecimento científico atravessa fases, começando pela pré-científica, seguida de um paradigma, no qual se desenvolve a ciência normal, um período de crise, uma revolução científica com o surgimento de um novo paradigma.

- Idealismo: a realidade é concebida em termos de espírito ou experiência;

- Relativismo: o foco se dá nos processos cognitivos, que envolvem representações e julgamentos que são compartilhados pelos cientistas, ou os conceitos são construções sociais que determinam o mundo, e não o contrário;

- Construtivismo: se opõe à investigação científica como descritiva, considerando que a realidade científica emerge progressivamente de um processo reflexivo.

Essas perspectivas dizem respeito não apenas ao conhecimento científico, mas também ao seu ensino. Gil-Pérez et al. (2001) chamam atenção para as evidências de que concepções epistemológicas inadequadas e/ou incorretas atuam como um dos principais obstáculos na renovação do ensino de Ciências.

O reflexo dos valores no Ensino de Ciências também pode ser compreendido nos trabalhos de Becker (1993), Gil-Pérez (2001) e Behrens (2013). Paradigmas empiristas, aprioristas e construtivistas fundamentam a construção de modelos educacionais. Entretanto, pesquisas atuais indicam que essas visões não são igualmente aceitáveis ou coerentes, seja com a construção do conhecimento científico ou seu ensino (CACHAPUZ et al., 2001; GIL-PÉREZ et al., 2001; GARCÍA-CARMONA, 2009).

Tais elementos podem ser encontrados nos modelos educacionais como tradicional, escolanovista e tecnicista, que prezam pela reprodução do conhecimento. Da mesma forma, com a mudança de paradigmas científicos, novos modelos educacionais surgem, como o holístico, o progressista e o investigativo.

Nesses modelos podemos identificar práticas, tanto educacionais, quanto científicas. Cada uma dessas abordagens apresenta um papel diferente para o professor, para o aluno, para a escola e para a avaliação. No que se refere ao Ensino de Ciências, podemos afirmar que as pesquisas hoje se estruturam em um paradigma construtivista, que tenta superar os paradigmas tradicionais (CACHAPUZ et al., 2001; MASSABNI, 2007; CARVALHO; GIL-PÉREZ, 2011). Entretanto, essa transposição não é um processo simples, e se depara com diversos desafios (MASSABNI, 2007; CARVALHO; GIL-PÉREZ, 2011).

É partindo dessa caracterização do modelo KVP que desenvolveremos nossa análise, que será descrita a seguir. 


\section{PERCURSOS METODOLÓGICOS}

Para identificar Representações Sociais de licenciandos a respeito do 'ser professor de Física' utilizamos duas abordagens. Em um trabalho anterior fizemos uso da evocação livre de palavras com o objetivo de analisar o núcleo central e as periferias dessas RS (ORTIZ; MAGALHÃES JÚNIOR, 2019).

No presente trabalho investigamos as concepções de licenciandos ingressantes e concluintes do curso de Física de uma universidade pública, região Norte do Paraná, a respeito do tema, utilizando o modelo KVP em uma abordagem mista, compreendida como uma combinação de técnicas quantitativas e qualitativas em um mesmo desenho de pesquisa (PARANHOS et al., 2016).

Participaram da pesquisa 25 alunos ingressantes no curso, sendo que 20 são do gênero masculino, quatro do gênero feminino e uma resposta indefinida. Já entre os concluintes, participaram 10 alunos, sendo sete do sexo masculino e três do sexo feminino. A idade média dos ingressantes foi de $18(17,91+/-0,55)$ anos, enquanto entre os concluintes essa média foi de $24(23,55+/-1,60)$ anos. Os participantes, bem como os docentes que estavam atuando na turma no momento da aplicação e o coordenador de curso autorizaram a coleta e o uso dos dados. O projeto foi avaliado e aprovado pelo comitê de ética de ambas as instituições participantes, sob os números 11832119.9.0000.8156 e 11832119.9.3001.0104.

\section{Coleta de dados}

A coleta de dados foi realizada por meio de um questionário composto por dados pessoais e 81 assertivas com opções de resposta de escala tipo likert composta por quatro pontos: concordo plenamente; concordo; discordo e discordo plenamente. Esse questionário foi validado semântica e estatisticamente (análise de fidedignidade) e ao final restaram 51 questões divididas entre Conhecimento (05), Práticas (12) e Valores (34) (MAGALHÃES JÚNIOR et al., 2020).

Magalhães Júnior et al. (2020) construíram as assertivas seguindo três dimensões: Epistemológica da Ciência, Ensino e Aprendizagem e Formação e Atuação Profissional Docente. Cada um desses núcleos contempla diferentes questões referentes aos três componentes KVP. Esse método leva em consideração a proposta de Clément (2010), que considera que uma concepção ou RS pode ser identificada ao comparar as respostas dos sujeitos à diferentes perguntas referentes ao mesmo tema.

Nos três quadros abaixo (Quadros 01, 02 e 03) detalhamos os objetivos e ideias centrais de cada dimensão para análise das concepções dos licenciandos, os indicadores utilizados para análise das principais ideias, e as assertivas que fazem parte desses indicadores.

Quadro 1 - Dimensão Epistemológica da Ciência e descrição dos indicadores de análise 1 - Dimensão Epistemológica da Ciência: Tem o objetivo de investigar as representações sobre a natureza da ciência que tramitam nas universidades e escolas de educação básica, considerando que estas influem na construção de saberes, na prática e identidade do ser professor de Ciências.

\begin{tabular}{|l|l|l|}
\hline Indicadores & Descrição & $\begin{array}{l}\text { Assertivas que } \\
\text { compõem }\end{array}$ \\
\hline $\begin{array}{l}\text { Indicador 1 - Visões } \\
\text { empírico-indutivistas da } \\
\text { ciência como obstáculo }\end{array}$ & $\begin{array}{l}\text { Avalia as representações que se opõem ou convergem com } \\
\text { a ideia de que o conhecimento científico resulta da } \\
\text { observação sistemática e imparcial dos fenômenos da } \\
\text { realidade, seguida da formulação de hipóteses, } \\
\text { experimentação e conclusão, isto é, de acordo com os } \\
\text { passos do método científico. }\end{array}$ & A28 \\
\hline $\begin{array}{l}\text { Indicador 2 - Visões } \\
\text { sobre o } \\
\text { desenvolvimento do } \\
\text { conhecimento científico }\end{array}$ & $\begin{array}{l}\text { Refere-se ao reconhecimento (ou não) dos complexos } \\
\text { processos históricos de mudanças no desenvolvimento do } \\
\text { conhecimento científico, opondo-se a uma visão } \\
\text { acumulativa e linear da ciência, fundamentada no produto } \\
\text { em detrimento dos processos de sua construção. }\end{array}$ & A7; A36 \\
\hline
\end{tabular}




\begin{tabular}{|l|l|c|}
\hline $\begin{array}{l}\text { Indicador 3 - Visões } \\
\text { sobre a natureza social e } \\
\text { coletiva do trabalho } \\
\text { científico }\end{array}$ & $\begin{array}{l}\text { Identifica representações que reconhecem (ou não) a } \\
\text { ciência como uma atividade social, coletiva, opondo-se a } \\
\text { uma visão individualista e elitista. }\end{array}$ & A19; A31 \\
\hline $\begin{array}{l}\text { Indicador 4 - Visão } \\
\text { objetiva e verdadeira de } \\
\text { ciência como obstáculo: }\end{array}$ & $\begin{array}{l}\text { Identifica representações que concordam (ou não) com a } \\
\text { ideia de que a ciência não dispõe de verdades absolutas, } \\
\text { mas de "acordos válidos" em determinados períodos } \\
\text { históricos. }\end{array}$ & $\begin{array}{c}\text { A4; A31; A33;A39; } \\
\text { A69 }\end{array}$ \\
\hline $\begin{array}{l}\text { Indicador 5 - Visões } \\
\text { sobre a relação Ciência e } \\
\text { Ideologia }\end{array}$ & $\begin{array}{l}\text { Investiga representações que reconhecem (ou não) que a } \\
\text { ciência não é neutra, mas influenciada por fatores sociais, } \\
\text { econômicos, culturais e ideológicos. }\end{array}$ & A19 \\
\hline
\end{tabular}

Fonte: Adaptado de Magalhães Júnior et al. (2020).

Quadro 2 - Dimensão ensino e aprendizagem e descrição dos indicadores de análise

2 - Dimensão ensino e aprendizagem: Pretende investigar as representações dos licenciandos e professores da educação básica acerca "do ensinar", do "aprender" e da práxis, fundamentando-se nas teorias epistemológicas sobre a origem do conhecimento, teorias psicológicas e pedagógicas de ensino e aprendizagem.

\begin{tabular}{|c|c|c|}
\hline Indicadores & Descrição & $\begin{array}{l}\text { Assertivas } \\
\text { que } \\
\text { compõem }\end{array}$ \\
\hline $\begin{array}{l}\text { Indicador } 6 \text { - Abordagem } \\
\text { tradicional }\end{array}$ & $\begin{array}{l}\text { Abrange representações que consideram o conhecimento } \\
\text { como algo exterior ao indivíduo (empirismo), adquirido por } \\
\text { meio da recepção passiva e mecânica de informações; que } \\
\text { valorizam a sistematização e transmissão de conhecimentos } \\
\text { acumulados pela humanidade (instrução coletiva) e } \\
\text { desconsideram as diferenças individuais. }\end{array}$ & A8; A14; A46 \\
\hline $\begin{array}{l}\text { Indicador } 7 \text { - Abordagem } \\
\text { tecnicista/redescoberta }\end{array}$ & $\begin{array}{l}\text { Compreende representações empiristas nas quais o } \\
\text { conhecimento é uma descoberta nova para o indivíduo, } \\
\text { resultante da observação direta dos fenômenos e da } \\
\text { experiência. Neste modo de pensar a aprendizagem ocorre } \\
\text { pela reestruturação do comportamento do indivíduo, } \\
\text { porém, de modo indutivo, mecânico e sensorial, por meio } \\
\text { da experimentação. O ensino, instrucional e individualizado, } \\
\text { é organizado por um conjunto de técnicas e materiais } \\
\text { didáticos que visam garantir a eficiência, avaliada pela } \\
\text { mudança de comportamento dos alunos. }\end{array}$ & $\begin{array}{c}\text { A2; A17; A20; } \\
\text { A34; A40; A46; } \\
\text { A49; A81 }\end{array}$ \\
\hline $\begin{array}{l}\text { Indicador } 8 \text { - Abordagem } \\
\text { humanista/racionalista }\end{array}$ & $\begin{array}{l}\text { Inclui respostas que levam em conta as condições biológicas } \\
\text { e motivacionais ao conceber como se dá o conhecimento } \\
\text { do indivíduo. Nesta abordagem a aprendizagem atua de } \\
\text { dentro para fora, por insight, sendo o professor apenas } \\
\text { facilitador do processo. O ensino baseia-se no } \\
\text { desenvolvimento de estratégias que possibilitam a liberdade } \\
\text { para aprender, enfatizando a autoavaliação. Abrange ideias } \\
\text { de que o aluno é um ser ativo, criativo e que aprende por si } \\
\text { próprio, desde que motivado. Valoriza não apenas a } \\
\text { aprendizagem de conhecimentos, mas também a afetiva, a } \\
\text { psicomotora. }\end{array}$ & $\begin{array}{c}\text { A52; A55; A64; } \\
\text { A77 }\end{array}$ \\
\hline $\begin{array}{l}\text { Indicador } 9-\text { Abordagem } \\
\text { cognitivista/construtivista }\end{array}$ & $\begin{array}{l}\text { Abarca representações que consideram que o conhecimento } \\
\text { não vem de dentro e nem está fora do indivíduo, mas resulta } \\
\text { de uma construção do sujeito ao interagir com o objeto de } \\
\text { conhecimento, com o meio físico, social e cultural. Ao } \\
\text { conceber que as funções mentais superiores têm origem } \\
\text { nessas interações, ou seja, não vêm prontas com o } \\
\text { nascimento do indivíduo, esta corrente de pensamento } \\
\text { privilegia estratégias que levam ao raciocínio, a elaboração } \\
\text { de ideias, e possibilitam a autonomia do aluno, baseando-se } \\
\text { no ensaio e erro, na pesquisa, na solução de problemas. O } \\
\text { controle da aprendizagem é avaliado pela assimilação e } \\
\text { aplicação do conhecimento em situações variadas. }\end{array}$ & $\begin{array}{l}\text { A67; A70; A72; } \\
\text { A75; A80 }\end{array}$ \\
\hline
\end{tabular}




\begin{tabular}{|l|l|c|}
\hline Indicador 10 - Abordagem & $\begin{array}{l}\text { Inclui as representações construtivistas que ressaltam a A58; A67; A72; } \\
\text { sociocultural }\end{array}$ & A78 \\
importância do contexto social e cultural, bem como das & \\
interações interpessoais no processo de elaboração de & \\
significados pelos estudantes. Nessa corrente de & \\
pensamento a organização do ensino decorre de problemas \\
e necessidades concretas do meio sociocultural, \\
considerando os conhecimentos científicos fundamentais \\
na construção de uma consciência crítica neutra, mas \\
influenciada por fatores sociais, econômicos, culturais e \\
ideológicos.
\end{tabular}

Fonte: Adaptado de Magalhães Júnior et al. (2020).

Quadro 3 - Dimensão da formação e das atividades docentes e descrição dos indicadores de análise 3 - Dimensão da formação e da atividade docente: Tem o objetivo de identificar as representações dos licenciandos e professores da educação básica acerca do que é "ser professor", de como deve ser sua formação e dos saberes docentes necessários à sua atividade e à construção de identidades.

\begin{tabular}{|c|c|c|}
\hline Indicadores & Descrição & $\begin{array}{l}\text { Assertivas que } \\
\text { compõem }\end{array}$ \\
\hline $\begin{array}{l}\text { Indicador } 11- \\
\text { Dimensão apriorística }\end{array}$ & $\begin{array}{l}\text { Considera as representações sobre para ser professor é } \\
\text { necessário dom, vocação e talento, de modo que } \\
\text { consideram a profissão como uma arte, uma missão. }\end{array}$ & A3; A30 \\
\hline $\begin{array}{l}\text { Indicador } 12- \\
\text { Dimensão personalista } \\
\text { (humanista) }\end{array}$ & $\begin{array}{l}\text { Constituem representações para as quais a profissionalidade } \\
\text { (aqui entendida como o conjunto de atributos indicados } \\
\text { socialmente para distinguir a profissão docente das demais) } \\
\text { se pauta em características pessoais das quais se sobressaem } \\
\text { a dedicação, o autocontrole; a capacidade de } \\
\text { relacionamento, de interagir e criar condições para que os } \\
\text { alunos aprendam e se desenvolvam como pessoas. Para } \\
\text { essas representações a formação de professores deve } \\
\text { enfatizar a autodescoberta, a tomada de consciência sobre } \\
\text { si, possibilitando a cada sujeito o seu desenvolvimento } \\
\text { pessoal, a aprender fazer uso de si mesmo para tornar-se } \\
\text { professor. }\end{array}$ & A47 \\
\hline $\begin{array}{l}\text { Indicador } 13- \\
\text { Dimensão tradicional ou } \\
\text { enciclopédica: }\end{array}$ & $\begin{array}{l}\text { Compreende respostas que representam o professor como } \\
\text { um sujeito especialista que domina os conteúdos específicos } \\
\text { da ou das disciplinas que leciona. Desse modo, representam } \\
\text { que o conhecimento do conteúdo é a característica mais } \\
\text { importante que o professor deve possuir. Os cursos } \\
\text { formadores devem propiciar uma formação especializada, } \\
\text { centrada no processo de ensino e aprendizagem de } \\
\text { conhecimentos científicos da área específica de determinada } \\
\text { especialidade. Ao fornecer uma forte formação científica e } \\
\text { escassa formação pedagógica, os cursos formadores } \\
\text { orientados por esta racionalidade perpetuam a separação } \\
\text { entre a teoria e a prática. }\end{array}$ & A9 \\
\hline $\begin{array}{l}\text { Indicador } 14- \\
\text { Dimensão Prática }\end{array}$ & $\begin{array}{l}\text { As representações que consideram que o professor aprende } \\
\text { a ensinar na vida profissional, com a experiência, ou seja, } \\
\text { com a própria prática por meio de tentativas e erros. }\end{array}$ & $\begin{array}{l}\text { Não contém } \\
\text { questões }\end{array}$ \\
\hline $\begin{array}{l}\text { Indicador } 15- \\
\text { Dimensão acadêmica - } \\
\text { abordagem } \\
\text { compreensiva): }\end{array}$ & $\begin{array}{l}\text { Representações que consideram o professor um intelectual } \\
\text { que, além de ter domínio de conhecimentos que estruturam } \\
\text { a (as) disciplina (s) que leciona, incluindo os aspectos } \\
\text { históricos e epistemológicos, apresenta também domínio } \\
\text { didático-pedagógico, isto é, formas de como ensinar este } \\
\text { conteúdo. Na perspectiva deste indicador, a formação de } \\
\text { professores está voltada para o desenvolvimento da } \\
\text { capacidade de os sujeitos realizarem a transposição didática }\end{array}$ & A27 \\
\hline
\end{tabular}

\footnotetext{
${ }^{4}$ Após a validação estatística do questionário, todas as questões que compunham o indicador 14 foram excluídas, o que implica que o mesmo não tem relevância para nossa pesquisa. 


\begin{tabular}{|c|c|c|}
\hline & $\begin{array}{l}\text { do conteúdo a ser ensinado, ou seja, de serem capazes de } \\
\text { transformar o conhecimento científico em saber escolar. }\end{array}$ & \\
\hline $\begin{array}{l}\text { Indicador } 16- \\
\text { Dimensão técnica }\end{array}$ & $\begin{array}{l}\text { As representações sobre o professor ser considerado um } \\
\text { técnico especialista que aplica na sua prática docente os } \\
\text { conhecimentos científicos e habilidades pedagógicas } \\
\text { adquiridos nos cursos formadores. As problemáticas } \\
\text { educacionais são consideradas problemas técnicos que } \\
\text { podem ser resolvidos por meio da racionalidade científica. } \\
\text { A aprendizagem de como ensinar decorre da aquisição de } \\
\text { conhecimentos e práticas provenientes de estudos } \\
\text { científicos sobre o ensino. Essa formação é influenciada por } \\
\text { teorias condutivistas ou comportamentalistas e seus } \\
\text { programas baseiam-se na utilização de materiais } \\
\text { instrumentais e modulares para facilitar a aquisição das } \\
\text { competências. }\end{array}$ & A56 \\
\hline $\begin{array}{l}\text { Indicador } 17 \text { - } \\
\text { Dimensão Ensino por } \\
\text { Competência }\end{array}$ & $\begin{array}{l}\text { Na LDB no 9394/96 e Parâmetros Curriculares Nacionais } \\
\text { para a Educação Básica o conceito de competência é } \\
\text { representado não como um saber rígido e repetitivo, tal } \\
\text { como considerado no indicador anterior, mas como a } \\
\text { capacidade de gerir e mobilizar vários recursos teóricos e } \\
\text { práticos, entre os quais os cognitivos, para resolver } \\
\text { problemas reais. Nessas representações os cursos } \\
\text { formadores devem contribuir para que os professores } \\
\text { desenvolvam competências para identificar, compreender e } \\
\text { resolver questões educacionais, com autonomia para a } \\
\text { tomada de decisões; responsabilidade pelas suas ações e } \\
\text { atitudes e, também, com conhecimentos para avaliar sua } \\
\text { atuação e o contexto no qual atua. Entre os saberes docentes } \\
\text { destacam-se, também, as competências para elaborar } \\
\text { coletivamente o projeto político pedagógico da escola, } \\
\text { utilizar diversos recursos didático-pedagógicos, planejar e } \\
\text { desenvolver diferentes estratégias de intervenção, avaliar o } \\
\text { processo educativo etc. (Brasil, 1999; Garcia, 1999). Nessa } \\
\text { perspectiva de formação é recomendado que a disciplina de } \\
\text { Prática de ensino seja ofertada desde o início do curso, de } \\
\text { modo a superar o modelo } 3+1 \text {. }\end{array}$ & A41; A65 \\
\hline $\begin{array}{l}\text { Indicador } 18- \\
\text { Dimensão Prática- } \\
\text { reflexiva }\end{array}$ & $\begin{array}{l}\text { As representações que consideram que a aprendizagem do } \\
\text { como ensinar ocorre por meio de um processo de reflexão } \\
\text { dos professores sobre sua prática. Esse processo de } \\
\text { reflexão, que deve começar na formação inicial e continuar } \\
\text { durante toda a vida profissional dos professores, permite- } \\
\text { lhes analisar e repensar sobre o ensino que proporcionam } \\
\text { aos estudantes, sobre suas ações e atitudes, sobre as teorias } \\
\text { implícitas à sua atividade docente. De acordo com estas } \\
\text { representações, a formação de professores (inicial e } \\
\text { continuada) deve ser orientada para a indagação, para a } \\
\text { investigação e reflexão na ação. Nessa perspectiva, o } \\
\text { professor assume um perfil prático-reflexivo, sendo } \\
\text { também representado como professor investigador e } \\
\text { problematizador; profissional autocrítico, flexível, ou seja, } \\
\text { aberto a mudanças; sujeito que resolve problemas, que toma } \\
\text { decisões etc. Esse processo de formação busca romper com } \\
\text { a dicotomia entre teoria e prática, contribuindo para que os } \\
\text { professores em formação inicial e continuada sejam capazes } \\
\text { de construir, produzir, ressignificar e compartilhar, com } \\
\text { outros professores, os conhecimentos produzidos por meio } \\
\text { de sua prática. Como o professor estará sempre se } \\
\text { autoconstruindo esta dimensão considera que as formações } \\
\text { inicial e continuada se constituem um único processo. }\end{array}$ & $\begin{array}{l}\text { A12; A15; A18; } \\
\text { A24; A41; A44; } \\
\text { A50; A62 }\end{array}$ \\
\hline
\end{tabular}




\begin{tabular}{|c|c|c|}
\hline $\begin{array}{l}\text { Indicador } 19- \\
\text { Dimensão social- } \\
\text { construtivista }\end{array}$ & $\begin{array}{l}\text { As representações abarcam, além das ideias apresentadas no } \\
\text { indicador anterior, a necessidade de práticas docentes } \\
\text { reflexivas e críticas que incorporam o compromisso ético e } \\
\text { social na busca de uma sociedade mais justa e democrática. } \\
\text { Para esta corrente de pensamento, a reflexão crítica não é } \\
\text { determinada biologicamente; não é individual e neutra, ou } \\
\text { simples produto do meio, de modo a reproduzir seus } \\
\text { valores, mas é coletiva, surge das relações sociais e volta-se } \\
\text { para a análise e transformação das práticas sociais e } \\
\text { ideológicas. Nessa consigna, a formação de professores, } \\
\text { além de possibilitar a construção de conhecimentos } \\
\text { específicos e pedagógicos, deve orientaro desenvolvimento } \\
\text { da capacidade de analisar o contexto social. Entre os saberes } \\
\text { necessários à docência destacam-se as capacidades de o } \\
\text { professor contextualizar e problematizar os conteúdos } \\
\text { escolares; de atuar como mediador entre dois pólos - } \\
\text { conhecimento e aluno; de preparar atividades, realizar } \\
\text { avaliações formativas, entre outros saberes. }\end{array}$ & A24; A41; A73 \\
\hline
\end{tabular}

Fonte: Adaptado de Magalhães Júnior et al. (2020).

Essas assertivas foram analisadas estatisticamente fazendo uso dos softwares SPSS $\mathbb{R}$ (Statistical Package for Social Sciences) e Microsoft Excel ${ }^{\circledR}$, conforme detalharemos na sequência.

\section{Análise de dados}

Conforme afirmamos anteriormente, fizemos uso de dois softwares para desenvolvermos uma análise estatística dos nossos resultados.

Na primeira etapa, inserimos no SPSS os dados coletados e, analisando as escalas Likert para as respostas, constatamos que as assertivas foram elaboradas de duas maneiras com relação às expectativas teóricas: a primeira diz respeito ao nível esperado de concordância com a afirmação, enquanto a segunda refere-se a afirmações que hipoteticamente deveriam apresentar discordância entre os respondentes. Assim, diante da necessidade de padronizar as respostas para a realização de nossas análises, as afirmações da segunda categoria foram recodificadas, de modo que sua escala de valoração de respostas foi invertida, conforme exemplificado no quadro abaixo (Quadro 4).

Quadro 4- recodificação das respostas esperadas em relação à escala likert.

\begin{tabular}{|l|c|c|c|c|}
\hline Questão & $\begin{array}{l}\text { Concordo } \\
\text { plenamen } \\
\text { te/valor }\end{array}$ & $\begin{array}{l}\text { Concordo/v } \\
\text { alor }\end{array}$ & Discordo/valor & $\begin{array}{l}\text { Discordo } \\
\text { plenamente/valor }\end{array}$ \\
\hline $\begin{array}{l}\text { Toda observação é feita } \\
\text { a partir de alguma } \\
\text { teoria. }\end{array}$ & 4 & 3 & 2 & 1 \\
\hline $\begin{array}{l}\text { Os alunos podem } \\
\text { aprender qualquer } \\
\text { conteúdo científico a } \\
\text { partir da observação e } \\
\text { experimentação }\end{array}$ & 1 & 2 & 3 & 4 \\
\hline
\end{tabular}

Fonte: os autores.

$\mathrm{Na}$ sequência, a fim de estabelecer maior precisão à análise, promovemos a redução das escalas de Likert a variáveis binárias, conforme a seguinte recodificação: respostas 1 e 2 foram recodificadas com valor 0 , o que significa ausência de acordo com a expectativa teórica, ao passo que respostas 3 e 4 atendem às expectativas teóricas anteriormente estabelecidas. 
A partir da recodificação de todas as assertivas, foi possível a elaboração de índices, que são indicadores construídos a partir da reunião de diferentes variáveis, a fim de proporcionar análises mais robustas acerca de fatores inter-relacionados.

Para tal redução, foi realizado o teste alpha de cronbach que permitiu a criação dos 19 índices, como exemplificado no quadro abaixo (Quadro 5). Cada indicador tem escala de variação entre 0 (que indica completa ausência de respostas em conformidade com a expectativa teórica) e n (que indica o número máximo de respostas em conformidade com a expectativa teórica), de modo que n equivale à quantidade total de assertivas que compõem cada indicador.

Quadro 5 - exemplo de indicador de análise.

\begin{tabular}{|l|l|c|c|}
\hline Indicador (índice) & $\begin{array}{l}\text { Questões que compõem o indicador } \\
\text { (índice) }\end{array}$ & $\begin{array}{c}\text { Número } \\
\text { total de } \\
\text { questões }\end{array}$ & $\begin{array}{c}\text { Índice } \\
\text { máximo de } \\
\text { concordância }\end{array}$ \\
\hline $\begin{array}{l}\text { Indicador 18 - } \\
\begin{array}{l}\text { Dimensão Prática- } \\
\text { reflexiva }\end{array}\end{array}$ & A12; A15; A18; A24; A41; A44; A50; A62 & 8 & 8 \\
\hline
\end{tabular}

Fonte: Os autores.

De posse desses dados, exportamos as informações para o Microsoft Excel, onde produzimos gráficos que representam os índices de concordância dos ingressantes e concluintes do curso de licenciatura em Física com cada um dos indicadores propostos. Por meio desse conjunto de ações, desenvolvemos uma análise estatística dos dados. Apresentaremos a seguir os resultados encontrados.

\section{CONHECIMENTOS, VALORES E PRÁTICAS EM LICENCIANDOS EM FÍSICA}

Para realizarmos nossa análise, faremos uso das três dimensões propostas por Magalhães Júnior et al. (2020): Epistemológica da Ciência; Ensino e Aprendizagem; Formação e atividade docente. Em cada uma dessas dimensões, buscaremos identificar os componentes KVP dos sujeitos de pesquisa, a fim de construir um possível retrato de suas concepções.

\section{Dimensão Epistemológica da Ciência}

Os resultados abaixo representam concepções relativas à natureza da Ciência identificada entre os participantes da pesquisa. Os primeiros cinco gráficos indicam o nível de concordância com cada um dos conceitos analisados.

Gráficos 1 e 2 - índice de concordância dos licenciandos com visões empírico-indutivistas da ciência (mín.0/máx.4) e índice de concordância dos licenciandos com visões do processo histórico de desenvolvimento do conhecimento científico (mín.0/máx.2). 


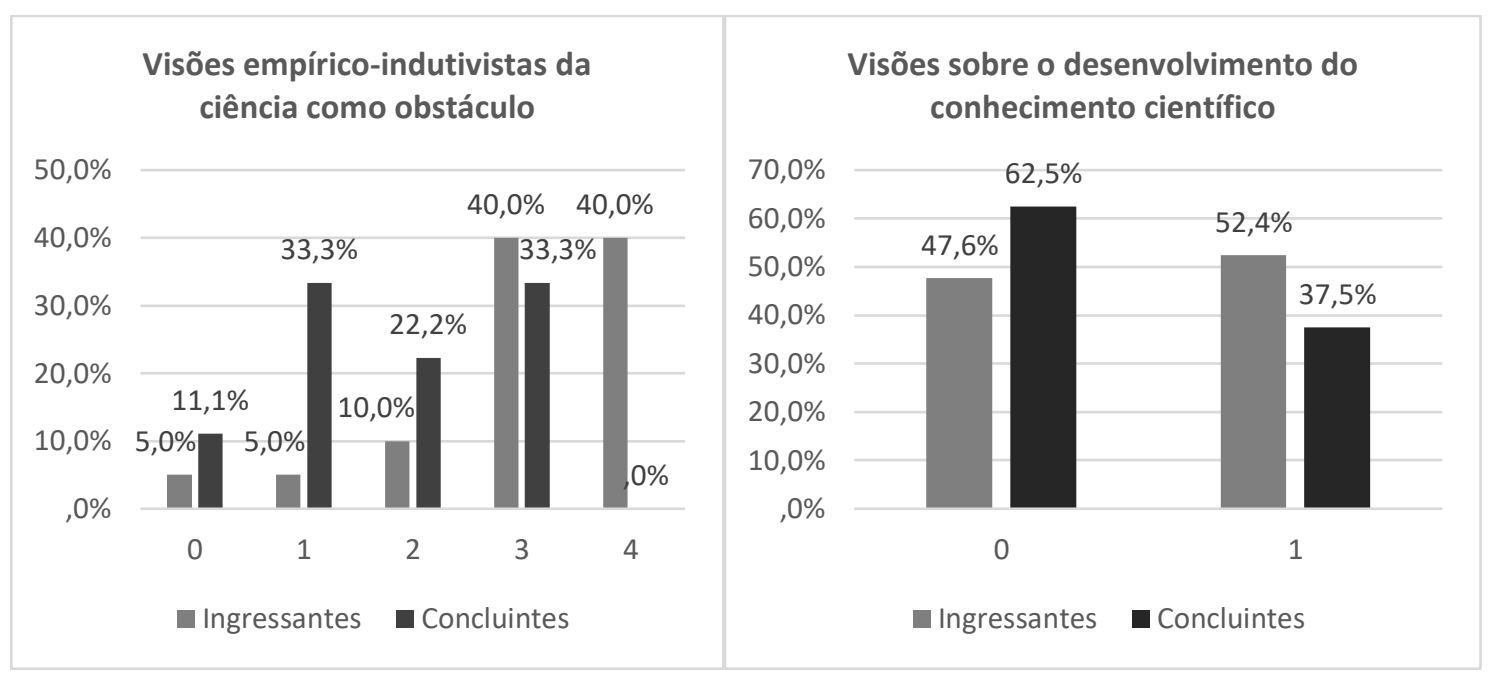

Fonte: Os autores.

O Gráfico 01 indica que a maior parte dos posicionamentos dos ingressantes do curso de licenciatura em Física exibe um elevado $(40 \%)$ ou total (40\%) grau de concordância com a perspectiva empírico-indutivista da Ciência. Essa concordância apresenta um leve regresso entre os concluintes, já que não identificamos total grau de concordância em nenhum deles. Entretanto, as premissas ainda encontram grande aceitação em 33,3\% de suas respostas e aceitação intermediária em 22,2\%. Isso implica que mais de $50 \%$ dos posicionamentos apresentados pelos concluintes concordam em algum grau com essa visão epistemológica.

Enquanto há uma redução na aceitação da perspectiva empirista ao final do curso, quanto a compreensão da construção do conhecimento científico como um processo complexo e não linear, chama atenção que o índice de considerações dos concluintes que discordam totalmente dessa interpretação é superior ao de ingressantes (62,5\% contra 47,6\%). Além disso, nenhum dos sujeitos investigados se encontram totalmente de acordo com as concepções teóricas nesse caso. Em outras palavras, essa mudança de concepções não se direcionou para uma interpretação fundamentada nas revoluções científicas. Para compreendermos essa relação, podemos analisar os gráficos 03 e 04.

Gráficos 3 e 4 - índice de concordância dos licenciandos com visões sobre a natureza social e coletiva do trabalho científico (mín.0/máx.2) e índice de concordância dos licenciandos com visões objetivas e verdadeiras de ciência (mín.0/máx.4).

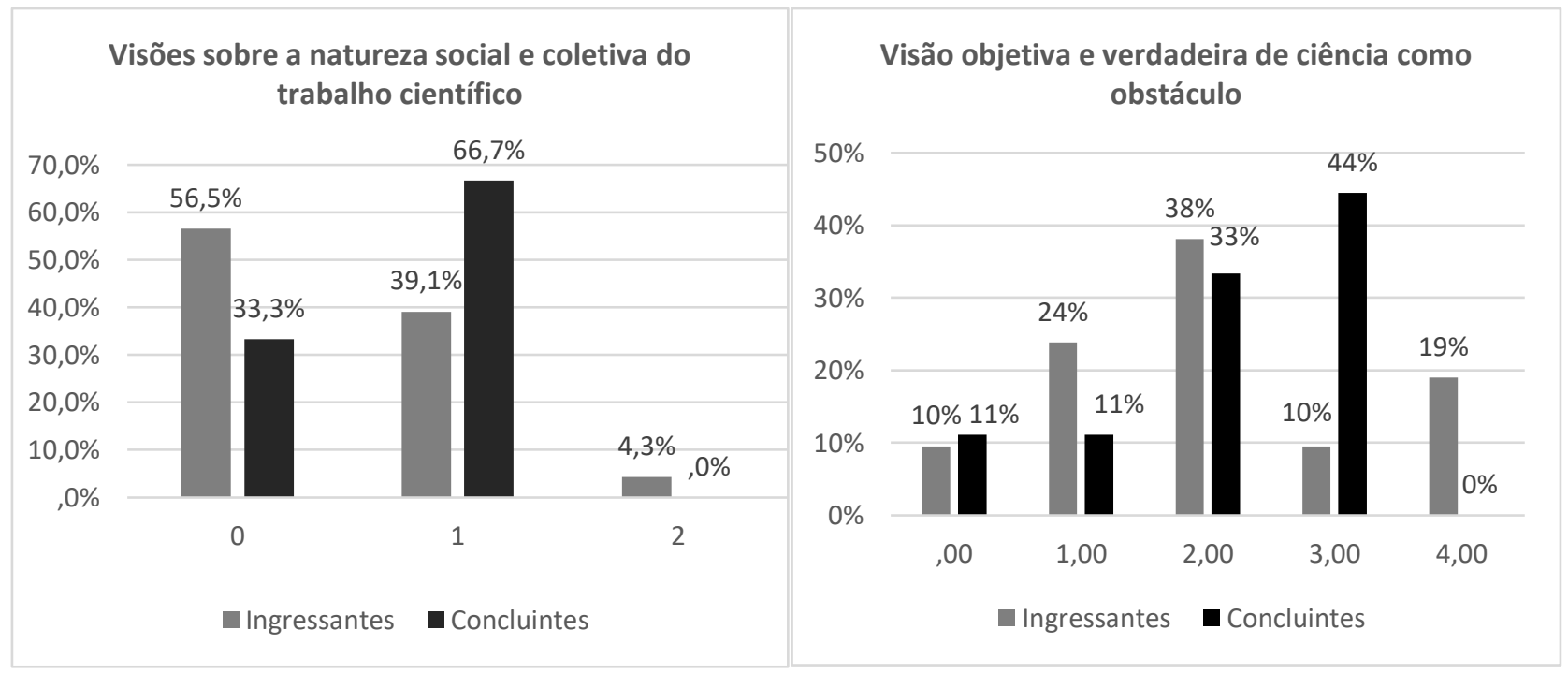

Fonte: Os autores.

No caso do gráfico $03,56,5 \%$ das respostas dos ingressantes do curso tem total grau de discordância com a ideia de que a ciência é uma atividade social e coletiva, enquanto $66,7 \%$ no caso dos 
concluintes concordam de maneira intermediária com essa premissa. No que se refere à concordância total com essas visões, o índice de concluintes é nulo e o de ingressantes pequeno $(4,3 \%)$ em comparação aos demais posicionamentos.

Já o indicador 04 apresenta que entre os concluintes, 44,4\% das opiniões concordam de maneira elevada e 33,3\% de maneira intermediária com a ideia de que a Ciência não dispõe de verdades absolutas, mas de "acordos válidos", enquanto 11,1\% discordam totalmente desses conceitos. Já entre os ingressantes há uma maior concordância com essa visão, sendo que 38,1\% das respostas concordam de maneira intermediária com a mesma, 9,5\% de maneira elevada e 19\% concordam totalmente.

O próximo gráfico (Gráfico 5) apresenta nosso último elemento de análise a respeito da dimensão epistemológica da Ciência. Nele podemos observar que 91,3\% das opiniões dos ingressantes discordam totalmente que a Ciência não é neutra e é influenciada por fatores externos. Entre os concluintes, a discordância perante esse indicador é de 100\%.

Gráfico 5 - índice de concordância dos licenciandos com a relação entre Ciência e Ideologia (mín.0/máx.1).

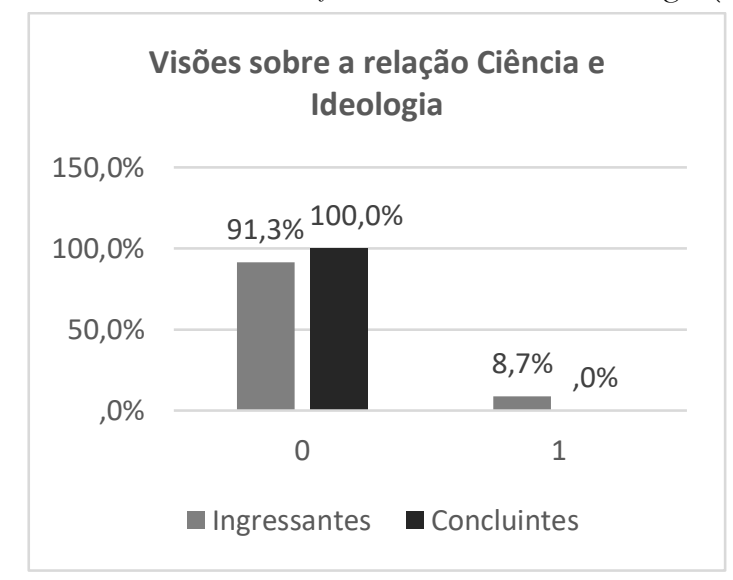

Fonte: Os autores.

A partir dessa análise, podemos traçar um perfil das concepções dos ingressantes e concluintes, dentro dos parâmetros KVP.

No caso dos ingressantes, identificamos que seu sistema de conhecimentos, valores e práticas se sustenta em uma visão empírico-indutivista da Ciência, na qual a fundação do conhecimento científico é proveniente da experimentação e da observação (GIERE; 1988; POOLE, 1995; ROSENBERG, 2000).

Apesar de alguns posicionamentos intermediários a respeito de indicadores epistemológicos que se aproximam de uma compreensão de características essenciais do conhecimento científico (GILPÉREZ et al., 2001), percebemos que a maior parte desse grupo discorda de uma concepção de ciência como um trabalho social e coletivo, e quase todo o grupo não concorda com a existência de influências externas e não científicas no processo de construção desse conhecimento. Por outro lado, se sobressai o conceito de que a ciência não é detentora de uma verdade absoluta.

Em linhas gerais, percebemos nos ingressantes dessa licenciatura em Física a presença das sete visões deformadas do conhecimento científico descritas por Gil Pérez et al. (2001), sendo elas a concepção empírico-indutivista e ateórica, visão rígida do método científico, visão aproblemática e ahistórica, visão exclusivamente analítica, visão acumulativa de crescimento linear visão individualista e elitista e uma imagem socialmente neutra da ciência.

Já em relação aos concluintes, é possível identificarmos algumas diferenças nas concepções quando comparadas ao grupo de ingressantes. No caso da visão empirista da Ciência, a mesma perde um pouco de força, haja vista que apesar de mais de 50\% do grupo concordar em algum grau com essa perspectiva, há uma maior distribuição, que vai desde aqueles que concordam pouco até aqueles que concordam muito, entretanto sem nenhum dos sujeitos concordarem totalmente (contra 40\% dos ingressantes que se encontravam nessa posição). Por outro lado, essa concepção não foi substituída por uma interpretação que considere os complexos processos históricos envolvidos na construção do 
conhecimento científico (GIERE; 1988; POOLE, 1995; ROSENBERG, 2000), o que nos aponta os $62 \%$ de discordância do indicador 02 .

Os concluintes também avançam no que se refere à compreensão da Ciência como uma construção humana e coletiva, interpretação proveniente do gráfico 03 , que aponta que $66,7 \%$ entendem de forma intermediária a Ciência como uma construção humana, e reforçada pelo gráfico 04, de acordo com o qual 67,7\% dos concluintes concordam de forma intermediária ou elevada com a interpretação de que a Ciência não possui "verdades dogmáticas", mas sim "acordos válidos". O campo conceitual epistemológico aberto aqui é muito amplo, e pode ir desde o Realismo Crítico até o Relativismo.

São os resultados do indicador 06 que nos auxiliam na superação dessa polissemia. De acordo com o mesmo, todos os concluintes discordam que a Ciência não é neutra e pode ser influenciada por fatores externos. Dessa forma, não se identificam traços de relativismo, construtivismo e idealismo nesses sujeitos, conforme descritos por Poole, 1995 e Rosenberg, 2000.

De posse desses dados, percebemos que os conhecimentos, valores e práticas desses concluintes estão um pouco menos alinhados com a visão empirista. Entretanto, não há uma aproximação mais profunda de características consideradas essenciais ao trabalho científico (GIL PÉREZ et al., 2001). Nesse sentido, esse grupo continua sendo influenciado de forma considerável por visões epistemológicas deformadas a respeito da Física.

\section{Dimensão Ensino-aprendizagem}

Após traçarmos um perfil das concepções dos licenciandos a respeito da dimensão epistemológica da Ciência, faremos a mesma análise em relação aos seus conhecimentos, valores e práticas relativos ao processo de Ensino e Aprendizagem de Física.

Inicialmente, identificamos o índice de concordância dos sujeitos de pesquisa em relação às abordagens tradicional e tecnicista. Os resultados podem ser observados abaixo (Gráficos 06 e 07 ).

Gráficos 6 e 7 - índice de concordância dos licenciandos com a abordagem tradicional (mín.0/máx.3) e índice de concordância dos licenciandos com a abordagem tecnicista (mín.0/máx.8).

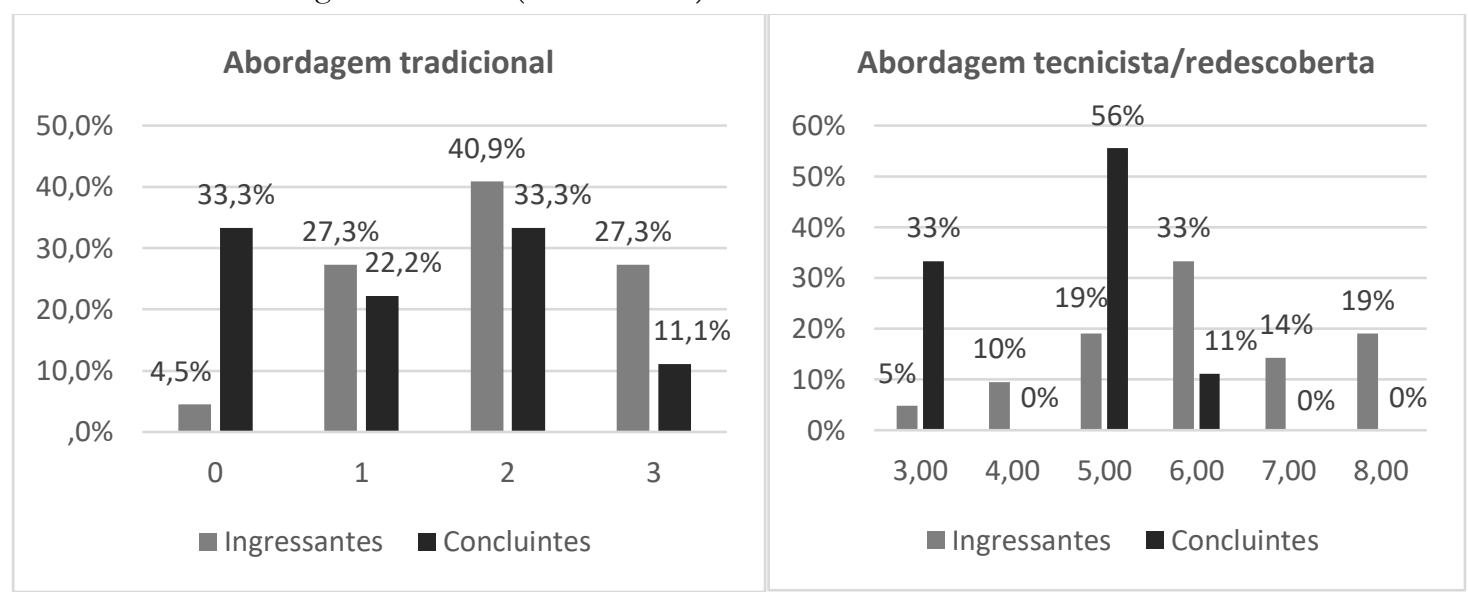

Fonte: Os autores.

Entre os ingressantes, o número de opiniões que concordam de maneira elevada ou totalmente com uma abordagem tradicional é de $68,2 \%$. Já entre os concluintes, percebemos um perfil mais heterogêneo, no qual $22,2 \%$ apresentam pouca e $33,3 \%$ nenhuma concordância com essa perspectiva de ensino, contra $33,3 \%$ de concordância elevada e $11,1 \%$ de total.

Esse quadro se repete entre os ingressantes quando consideramos a abordagem tecnicista. $47,6 \%$ dos posicionamentos desses sujeitos apresentam grande concordância (entre 6 e 7) com esse modelo e 19\% apresentam total concordância. Entre os concluintes, o menor grau de concordância identificado foi de 3 pontos (33,3\% dos sujeitos), mas ainda assim 55,6\% apresentam um grau intermediário (5) e 11,1\% um grau moderado (6) de concordância com essa perspectiva. Apesar de 
nenhum deles concordar totalmente com essa abordagem, não há discordância significativa entre nenhum dos grupos a respeito da mesma.

Já os indicadores de uma abordagem humanista e construtivista são apresentados nos Gráficos abaixo (8 e 9).

Gráficos 8 e 9 - índice de concordância dos licenciandos com a abordagem humanista (mín.0/máx.4) e índice de concordância dos licenciandos com a abordagem construtivista (mín.0/máx.5).

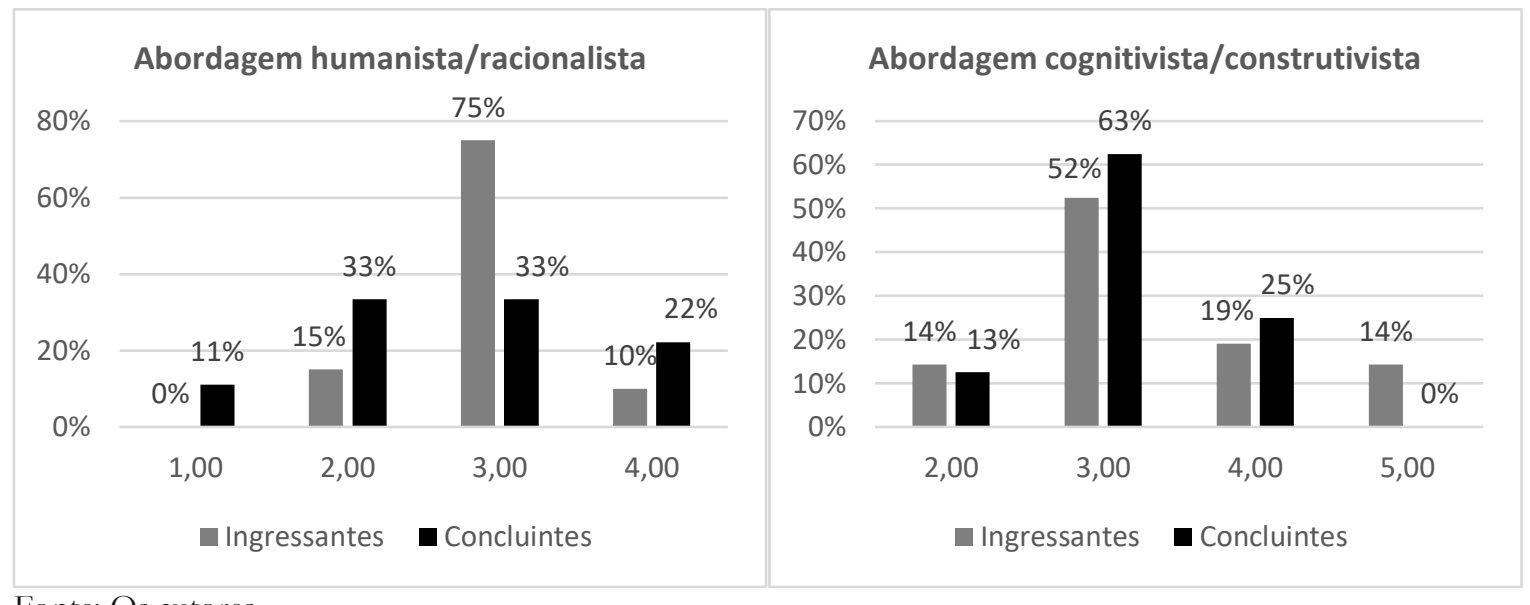

Fonte: Os autores.

De acordo com esses resultados, $85 \%$ das respostas dos ingressantes concordam de forma elevada ou totalmente com uma abordagem humanista, enquanto entre os concluintes há um aumento de posicionamentos extremos (ou próximos) da interpretação dessa abordagem $(11,1 \%$ discordam fortemente e 22,2\% concordam totalmente). Enquanto isso, $66,6 \%$ do grupo concorda de forma intermediária ou moderada com a influência das condições biológicas e motivacionais no conhecimento do indivíduo.

Já no que se refere à interpretação que o conhecimento resulta da construção do sujeito a partir da interação com o objeto de conhecimento (cognitivista/construtivista), a concordância varia entre intermediária e moderada ( 2 e 3), elevada (4) e total (5) nos ingressantes do curso, sendo que a maior parte concorda de maneira moderada com esses preceitos (52,4\%) e 14,3\% concordam totalmente. Por outro lado, há uma redução do grau de concordância entre os concluintes, que se concentram em uma aceitação moderada desses preceitos $(62,5 \%)$ sem nenhum posicionamento totalmente de acordo.

Quanto a abordagem sociocultural, aquela que ressalta a importância do contexto social e cultural, bem como das interações interpessoais ao longo do processo, 38,1\% dos ingressantes e 33,3\% dos concluintes concordam de forma intermediária, enquanto $42,9 \%$ dos ingressantes e $33,3 \%$ dos concluintes concordam de maneira elevada com essas concepções. Entretanto há um crescimento entre aqueles que concordam totalmente $(14,3 \%$ versus $22,2 \%)$ e um crescimento ainda maior entre os que discordam fortemente (de 4,8\% para 11,1\%). Além disso, nenhuma das opiniões de ambos os grupos discordou totalmente dessa abordagem.

Gráficos 10 - índice de concordância dos licenciandos com a abordagem sociocultural (mín.0/máx.4). 


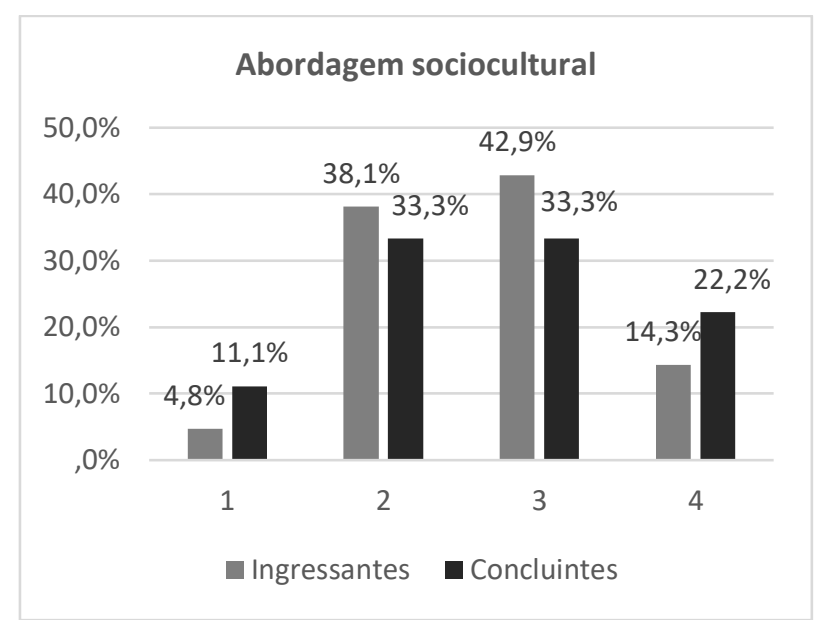

Fonte: Os autores.

São esses indicadores que utilizamos para traçar um perfil das concepções dos licenciandos participantes dessa pesquisa a respeito do processo de ensino e aprendizagem da Física.

Entre os ingressantes foi possível identificar que seus conhecimentos, valores e práticas são bastante imprecisos. Modelos opostos como do tradicionalismo e sociocultural encontram respaldo entre eles. Mesmo se olharmos para os maiores índices de concordância, mais de 68\% de suas opiniões concordam (de maneira elevada ou total) com uma abordagem tradicional, ao mesmo tempo que $85 \%$ apresentam a mesma concepção em relação a abordagem humanista/racionalista. Os modelos tradicionais se destacam apenas quando nos concentramos nos níveis de concordância. Nesses casos, as perspectivas tradicional e tecnicista se sobressaem perante as demais.

Esse resultado é compreensível se considerarmos que a construção dos saberes docentes se dá ao longo da formação e da prática, e os licenciandos tem ideias, atitudes e comportamentos que são consequência do longo período em que foram alunos (SALAZAR, 2005; HENZE; VAN DRIEL; VERLOOP, 2006; CARVALHO; GIL-PÉREZ, 2011). Tal confusão é compreensível se pensarmos que, como indicam Ortiz e Magalhães Júnior (2019), os estudantes desse curso vivenciam em seus dois primeiros anos a mesma formação que um bacharel, sendo que apenas no terceiro ano de curso terão contato com alguma formação pedagógica.

Já entre os concluintes do curso, esperávamos encontrar um perfil docente mais solidificado, no sentido de apresentarem coerência com um modelo de ensino, ou serem capazes de identificar divergências internas entre eles, considerando que os mesmos já tiveram contato com conhecimentos teóricos e práticos relativos à prática docente.

Entretanto, o que os resultados indicaram é que nenhuma das abordagens apresentam hegemonia nesse grupo, atuando então como delimitadoras de diálogos, conforme definição de Moscovici, 2015. Ainda assim, os graus de concordância com abordagens tradicionalistas/tecnicistas, consideradas juntamente as aceitações intermediárias/moderadas de abordagens construtivistas, indica que imagens espontâneas do ensino ainda permeiam suas representações, o que pode leva-los a encontrar dificuldades em orientar o processo de ensino de maneira construtivista e retornar às práticas positivistas (CARVALHO; GIL-PÉREZ, 2011). Nesse sentido, é até possível que esses sujeitos coloquem em prática alguns elementos construtivistas, entretanto, esses provavelmente irão coexistir com o modelo tradicional (MASSABNI, 20075).

\footnotetext{
${ }^{5}$ Chamamos atenção para o fato de a autora não considerar isso como um elemento necessariamente negativo, defendendo que ao investigar o trabalho docente, o construtivismo é um pressuposto teórico válido, porém não pode ser colocado em prática o tempo todo (MASSABNI, 2007).
} 


\section{Dimensão da formação e da atividade docente}

Nossa última dimensão de análise trata das concepções apresentadas pelos licenciandos a respeito do "ser professor de Física". Aqui contamos com oito indicadores, que discutiremos a seguir.

Gráficos 11 e 12 - índice de concordância dos licenciandos com a dimensão apriorística (mín.0/máx.2) e índice de concordância dos licenciandos com a dimensão humanista (mín.0/máx.1).

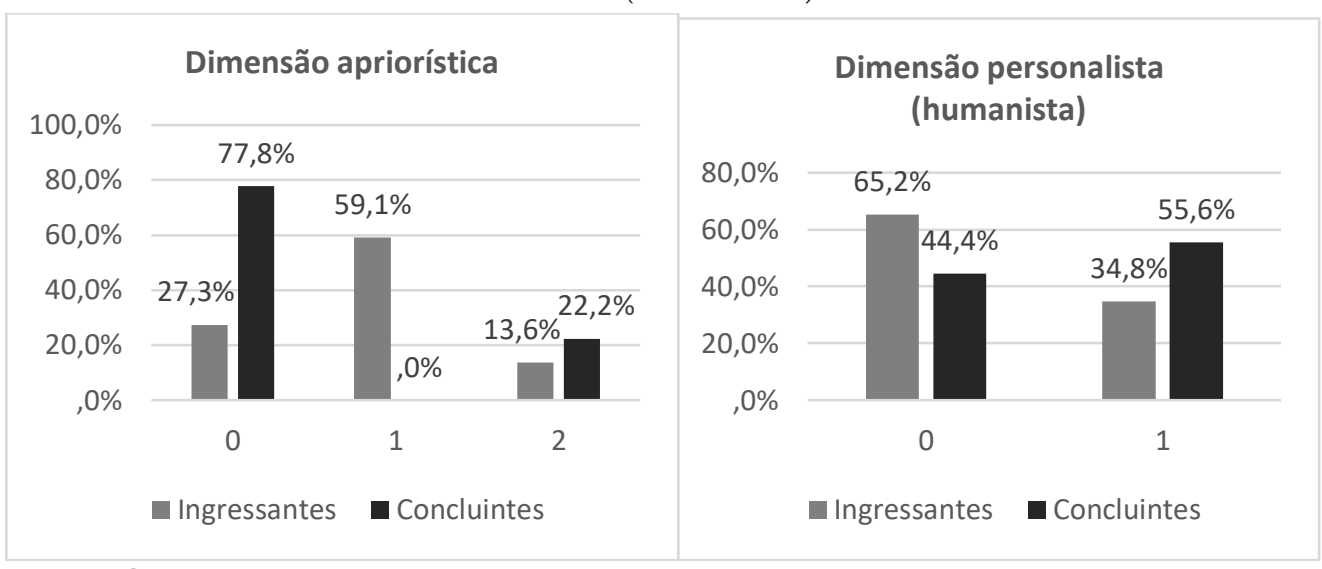

Fonte: Os autores.

O Gráfico 11 nos indica que 59,1\% das opiniões dos ingressantes concordam de maneira intermediária e 13,6\% concordam totalmente que a profissão docente é uma "missão" e, portanto, se faz necessário possuir um dom, vocação e talento. Nesse sentido, o conhecimento é algo inerente ao sujeito, já existe e apenas precisa ser despertado.

Esse quadro se altera entre os concluintes, entre os quais $77,8 \%$ das respostas discordam totalmente de tal interpretação, apesar de 22,2\% dos posicionamentos ainda apresentar total concordância com a mesma.

Já no que se refere à dimensão personalista, que valoriza o desenvolvimento pessoal e evidencia características como autocontrole, capacidade de relacionamento e criação de condições para que os alunos aprendam e se desenvolvam, $34,8 \%$ dos posicionamentos entre os ingressantes e 55,6\% entre os concluintes concordam totalmente com esse perfil docente.

Os próximos Gráficos (13 e 14) nos indicam o grau de concordância com a dimensão tradicional, que compreende o professor como especialista e o conhecimento do conteúdo é a característica mais importante que o professor deve possuir. Já na dimensão acadêmica, o professor é um intelectual que além de dominar o conteúdo, apresenta domínio epistemológico e didático pedagógico.

Gráficos 13 e 14 - índice de concordância dos licenciandos com a dimensão tradicional (mín.0/máx.1) e índice de concordância dos licenciandos com a dimensão compreensiva (mín.0/máx.1). 


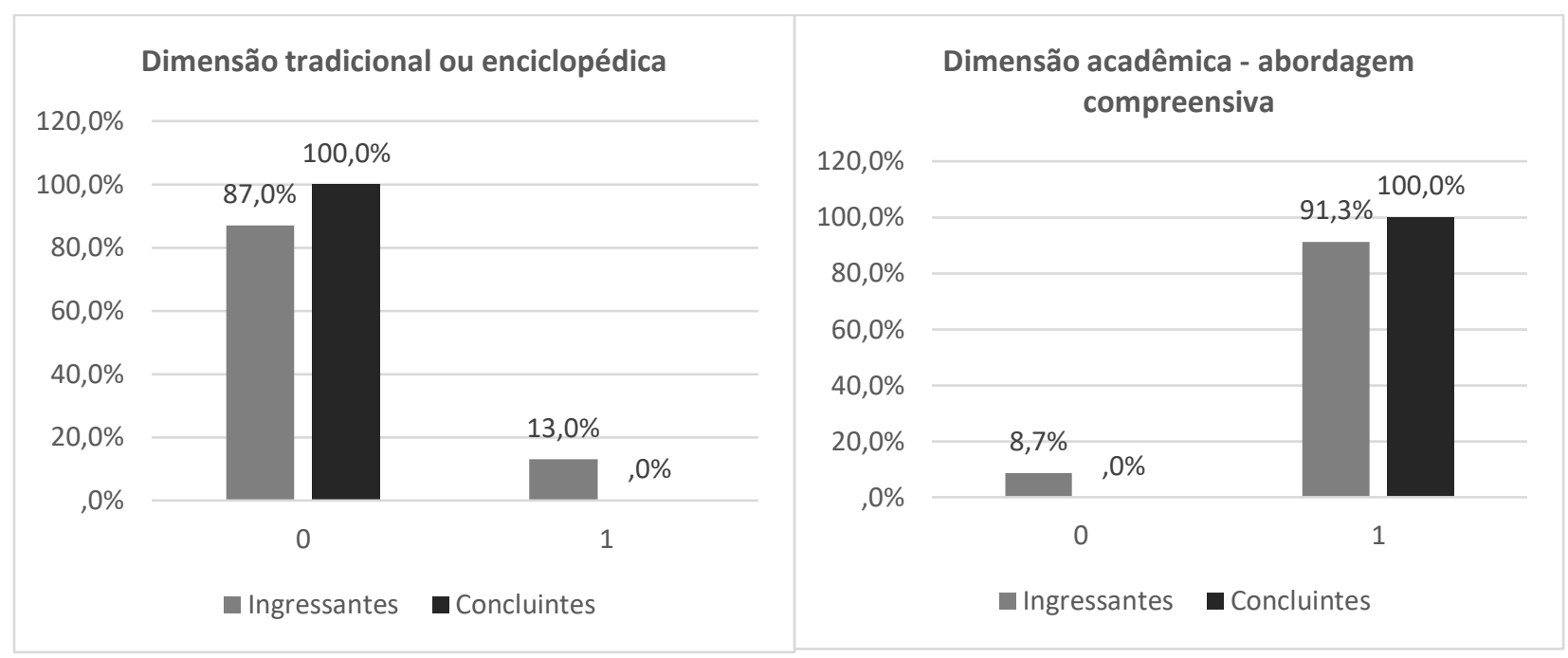

Fonte: Os autores.

Nesses casos a grande maioria das opiniões dos ingressantes (87\%) e todas as dos concluintes discordam do modelo tradicional/enciclopédico, enquanto 13,0\% dos posicionamentos dos ingressantes concordam totalmente com essa dimensão.

Por outro lado, esse quadro se reverte quando tratamos do modelo acadêmico/compreensivo, no qual as ideias de $91,3 \%$ dos ingressantes e $100 \%$ dos concluintes se mostram totalmente de acordo, contra $8,7 \%$ entre os ingressantes que se mostram totalmente contrárias à essa perspectiva.

As próximas dimensões analisadas são a técnica e o ensino por competências (Gráficos 15 e 16).

Gráficos 15 e 16 - índice de concordância dos licenciandos com a dimensão técnica (mín.0/máx.1) e índice de concordância dos licenciandos com a dimensão ensino por competências (mín.0/máx.2).

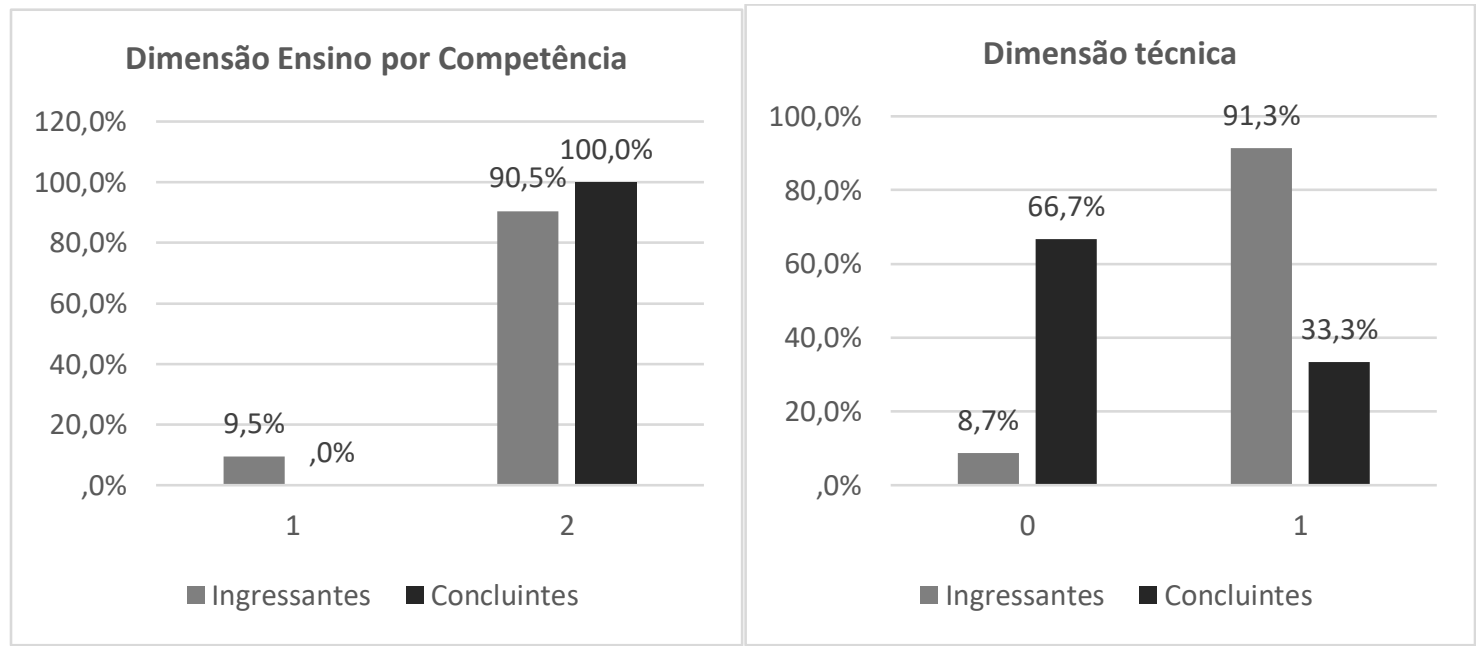

Fonte: Os autores.

No caso da dimensão técnica, 91,3\% dos posicionamentos dos ingressantes concordam totalmente que o professor é um técnico que aplica na sua prática conhecimentos científicos e habilidades pedagógicas adquiridas ao longo da sua formação, fundamentando-se em teorias comportamentalistas. Esse número é reduzido entre os concluintes, cujos $66,7 \%$ das opiniões discordam totalmente dessa premissa, contra 33,3\% que concordam totalmente.

Quanto ao Ensino por competências, ele é compreendido pela capacidade de gerir e mobilizar diferentes recursos teóricos e práticos para resolver problemas reais. Os professores precisam 
desenvolver diferentes competências, bem como autonomia para tomarem decisões. O índice de total concordância com essa dimensão é de $90,5 \%$ entre os ingressantes e 100\% entre os concluintes.

As duas últimas dimensões analisadas são a prática-reflexiva (Gráfico 17) e a social construtivista (Gráfico 18). No primeiro caso, o professor aprende a ensinar a partir da reflexão sobre sua prática. Esse processo é contínuo e o professor assume um perfil investigador, problematizador e autocrítico. Sessenta e dois porcento das opiniões dos ingressantes concordam fortemente com esse perfil docente, número que aumenta para $75 \%$ entre os concluintes. Por outro lado, 4,8\% dos posicionamentos dos ingressantes concordam totalmente com essas premissas, enquanto nenhum concluinte se encontra nesse grau de concordância.

Já na dimensão social construtivista, além das necessidades presentes na prática-reflexiva, se incorporam compromissos éticos e sociais. A reflexão não é individual ou neutra, mas fruto de um meio. Assim, se faz necessária a capacidade de analisar os contextos sociais. Quarenta e cinco e meio porcento das respostas dos ingressantes concordam de maneira elevada com essas premissas, ante $25 \%$ dos concluintes. Já entre as opiniões que concordam totalmente com essa perspectiva, estão 36,4\% dos ingressantes e $75 \%$ dos concluintes. Esses resultados podem ser observados nos gráficos 17 e 18.

Gráficos 17 e 18 - índice de concordância dos licenciandos com a dimensão prática-reflexiva (mín.0/máx.8) e índice de concordância dos licenciandos com a dimensão social-construtivista (mín.0/máx.3).

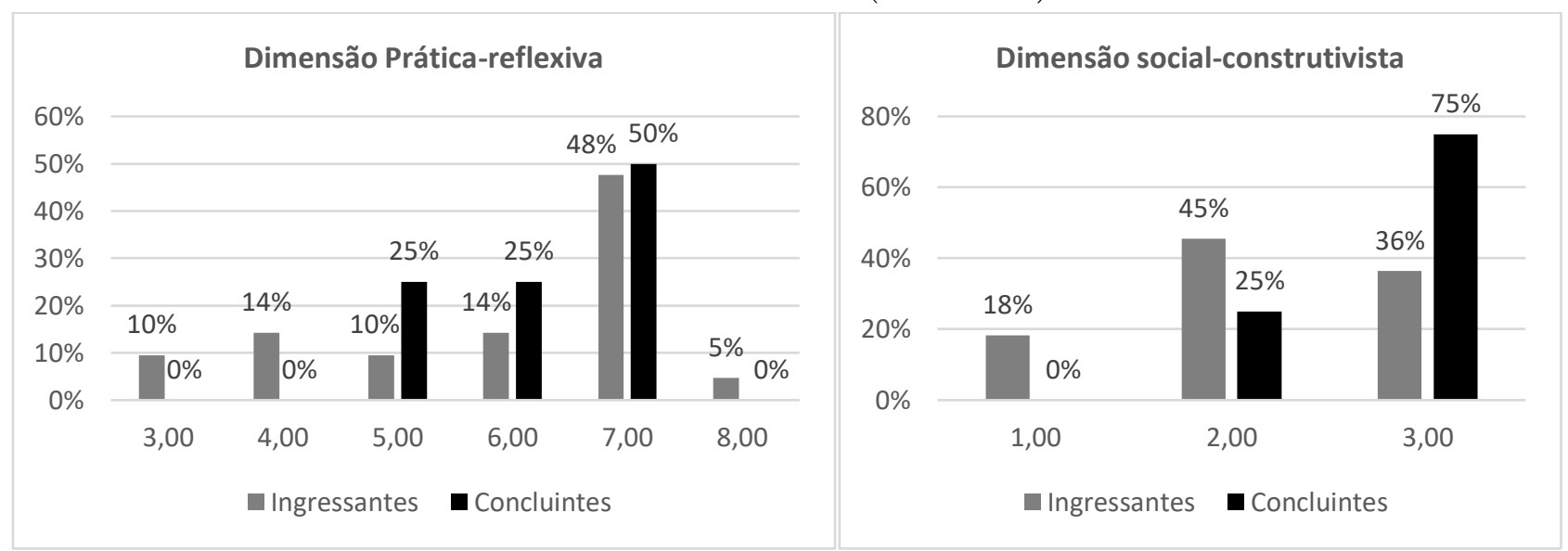

Fonte: Os autores.

Podemos identificar os seguintes Conhecimentos, Valores e Práticas entre os ingressantes da licenciatura: a maior parte concorda em algum grau com uma concepção apriorística, em contraposição à abordagem humanista. Nessa perspectiva o conhecimento faz parte da bagagem hereditária do aprendiz, seja de forma inata ou por meio da maturação (BECKER, 1993). O papel do professor nesse caso é "despertar" o conhecimento no aluno e fatores externos (como má alimentação, moradia inapropriada) não devem interferir no processo.

Além disso, se sobressaem em suas respostas as abordagens acadêmica, técnica, por competências e prático-reflexivas. Dessa forma, esses licenciandos não percebem contradições presentes entre esses diferentes paradigmas, no que diz respeito ao papel do professor, do aluno, da escola e da avaliação.

Em relação aos concluintes é relevante notar a elevada rejeição às concepções apriorística e tradicional. Por outro lado, temos uma possível hegemonia entre esse grupo, representada pelos elementos da Abordagem compreensiva e do Ensino por competências. Apesar disso, os índices de aceitação das dimensões prática-reflexiva e social-construtivista permitem a existência de controvérsias dentro do grupo, o que está de acordo com a teoria das RS (MOSCOVICI, 2015).

Diante desses resultados, compreendemos que os concluintes apresentam maior rejeição as características do trabalho docente relacionadas a modelos tradicionais de ensino. Entretanto, sua maior aproximação é com perspectivas que, apesar compreenderem o trabalho e a formação docente como mais do que dominar o conteúdo, ainda se concentra no desenvolvimento de capacidades e habilidades 
de ensino, apresentando menor aceitação de elementos construtivistas e reflexivos (GARCÍACARMONA, 2009; CARVALHO; GIL-PÉREZ, 2011).

Como já tratamos anteriormente, esse resultado é compreensível, podendo ser um reflexo do modelo de formação, que apesar de não se tratar de um formato $3+1$, altera apenas a quantidade da carga pedagógica (em um modelo 2+2), mantendo, entretanto, a formação clássica, em que primeiro se aprende Física para posteriormente desenvolver conhecimentos pedagógicos, o que se mostra uma forma equivocada e perigosa de entender a formação de professores (CACHAPUZ, 2001; CARVALHO; GILPÉREZ, 2011; ORTIZ; MAGALHÃES JÚNIOR, 2018; 2019).

\section{KVP E REPRESENTAÇÕES SOCIAIS SOBRE “SER PROFESSOR DE FÍSICA”: O QUE PODEMOS COMPREENDER?}

Iniciamos nossa análise dividindo as concepções em três dimensões (MAGALHÃES JÚNIOR et al., 2020), porém como Shulman (1986; 1987), Gil Pèrez e Vilches (2004) e Salazar (2005) evidenciam, os conhecimentos profissionais do professor não são formados por conceitos separados e individuais, mas sim por sua interrelação na construção do Conhecimento Pedagógico do Conteúdo. Dessa forma, vamos agora propor um quadro geral das concepções apresentadas por esses licenciandos na tentativa de compreender como elas podem influenciar na construção de suas representações sociais a respeito do 'ser professor de Física'.

Nos ingressantes do curso de licenciatura em Física evidenciamos que seus conhecimentos, valores e práticas a respeito da construção do conhecimento científico estão alinhados com uma concepção empírico-indutivista da Ciência (POOLE, 1995; GIL PÉREZ et al., 2001). Tal resultado se encontra de acordo com Becker (1993) e Gil Pérez et al. (2011), no sentido que o empirismo é a visão que mais caracteriza a epistemologia do professor de ciências, e os licenciandos trazem uma formação ambiental de seu período enquanto alunos.

Analisando as dimensões pedagógicas, esses ingressantes apresentam um elevado grau de concordância com modelos tradicionais e tecnicistas. Por outro lado, não rejeitam modelos construtivistas de ensino. O grupo não identifica as contradições consequentes desse posicionamento, de forma que prezam por conhecimentos teóricos a respeito da aprendizagem em ciências, porém que acabam se perdendo entre os pensamentos de senso comum (CARVALHO; GIL-PÉREZ, 2011).

Esse resultado é compreensível, por se tratarem de ingressantes, que ainda não tiveram a oportunidade de desenvolver uma reflexão crítica a respeito da prática docente, que os possibilite a tomar consciência da impregnação do ensino tradicional em suas concepções, mesmo que permeado por elementos construtivistas (GIL-PÉREZ et al., 2001; MASSABNI, 2007; CARVALHO; GIL-PÉREZ, 2011)

No que se refere ao papel do professor e a formação docente que esses ingressantes esperam, a abordagem apriorística, que considera a docência uma "missão", um dom que exige talento, ao lado da dimensão técnica, que pensa o professor como um técnico que aplica conhecimentos científicos juntamente às técnicas pedagógicas, constroem uma representação do professor dentro do que Behrens (2013) define como paradigmas tradicionais, ao mesmo tempo que reforçam a concepção de que "ser professor" implica conhecer o conteúdo e possuir "bom senso" (ORTIZ; MAGALHÃES JÚNIOR, 2018).

Essas concepções são atenuadas pelo elevado índice de concordância total com a dimensão acadêmica (compreensiva), que preza pela capacidade de o sujeito transformar saber científico em saber escolar, bem como com o ensino por competência que caracteriza o professor como aquele capaz de identificar, compreender e resolver questões educacionais, com autonomia para a tomada de decisões; responsabilidade pelas suas ações e atitudes e, também, com conhecimentos para avaliar sua atuação e o contexto no qual atua.

Essas são características de conhecimentos esperados na composição da base de conhecimentos (SHULMAN, 1986;1987; SALAZAR, 2005), entretanto, essas dimensões não se afastam efetivamente da perspectiva que a profissão docente é composta pelo domínio do conteúdo, 
acompanhado da prática e alguns saberes psicopedagógicos. O que ocorre é que os últimos ganham um papel mais relevante do que frente às dimensões tradicionais.

Por outro lado, as dimensões prática-reflexiva e social-construtivista não são rejeitadas, apesar de encontrarem menor índice de aceitação no grupo. Isso pode significar um conflito entre o tipo de docência que desejam e aquele que efetivamente tiveram, situação que pode ser utilizada para que tomem consciência da formação docente que adquiriram ambientalmente e possam submetê-la a uma reflexão crítica (CARVALHO; GIL-PÉREZ, 2011).

Esses resultados se mostram de acordo com a proposta de Salazar (2005), Zainko (2010), Carvalho e Gil-Pérez (2011) e Hilger e Moreira (2016) no que se refere a existência de conhecimentos e experiências prévias que podem influenciar na formação docente. O modelo tradicional ainda se encontra em evidência no ensino de Física na Educação Básica. Dessa forma, é compreensível que ao iniciar o curso os alunos compreendam a Física e seu Ensino em uma perspectiva empirista/tecnicista, e mesmo acreditando que o professor precisa transformar saberes científicos em escolares e precisam refletir a respeito da sua prática, encontram dificuldade em pensar essa perspectiva afastada de concepções apriorísticas e tecnicistas.

Voltemos agora nossos olhares para os concluintes desse curso. Quando se trata do seu sistema de conhecimentos, valores e práticas científicas eles se distanciam de concepções empiristas e se aproximam de uma compreensão da ciência como construção social e humana. Por outro lado, seus posicionamentos são intermediários nessa perspectiva, além de apresentarem total discordância com possíveis relações entre Ciência e ideologia.

Isso os coloca próximos de uma perspectiva realista, sem, entretanto, se aprofundarem em um realismo crítico, nem abandonarem a perspectiva empirista (GIERE; 1988; BECKER, 1993; POOLE, 1995; ROSENBERG, 2000).

No que se refere às práticas no ensino de Física, os licenciandos que chegaram à etapa final do curso apresentam características das mais variadas e contraditórias abordagens. Por um lado, esse resultado é preocupante, por apresentar indícios que ao longo da formação inicial esses sujeitos não construíram um perfil docente, mas sim uma miscelânea de características, muitas vezes contraditórias. Isso pode levá-los ao longo de sua prática a retornarem para paradigmas mais próximos do senso comum, como o empirista e o apriorista (BECKER, 1993; CARVALHO, GIL-PÉREZ, 2011).

Ainda assim, há uma redução na concordância com os modelos tradicionais de ensino e uma aceitação intermediária quanto aos modelos construtivistas e humanistas. Entretanto, não há mudanças expressivas no que se trata dos conhecimentos necessários à prática docente, o que se esperava que ocorresse ao longo da formação (SHULMAN, 1986; 1987; GIL PÉREZ; VILCHES, 2004; SALAZAR, 2005).

Quanto ao papel do professor e sua formação, observamos que há uma mudança de entendimento em relação aos ingressantes. Nessa etapa da formação os licenciandos consideram, em sua maioria, que a profissão se pauta em características pessoais das quais se sobressaem a dedicação, o autocontrole; a capacidade de relacionamento, de interagir e criar condições para que os alunos aprendam e se desenvolvam como pessoas.

Além disso, a rejeição aos modelos tradicionais de docência como o tradicionalismo e o tecnicismo é bem mais acentuada, sendo substituídos principalmente pelas abordagens compreensiva e por competências. As propostas construtivistas também apresentam maior grau de aceitação, porém ainda inferiores às duas anteriores.

Ao mesmo tempo que concepções relativas à Física como "portadora de verdades" vai sendo substituída pela compreensão da Física como "construção humana dentro da história", os modelos de ensino tradicionais perdem apoio frente àqueles construtivistas e investigativos e o papel do professor deixa de ser visto como "dono do conhecimento", passando a atuar como um "problematizador" reflexivo e crítico.

Dessa forma, compreendemos que houve diferenças nas concepções desses sujeitos, que apresentam conhecimentos teóricos a respeito da aprendizagem em Ciências, entretanto continuam presentes e aceitos os pensamentos de senso comum (CARVALHO; GIL-PÉREZ, 2011). Nesse sentido, o mais provável é que os sujeitos tenham incorporado elementos construtivistas ao modelo tradicional 
de ensino (MASSABNI, 2007), entretanto, não assimilaram esses elementos como igualmente coerentes e mais eficazes que o ensino tradicional, mas como retoques específicos desse último (CARVALHO; GIL-PÉREZ, 2011).

Continuando nossa busca por relações entre essas concepções e as representações sociais sobre "ser professor de Física", vamos resgatar os elementos de RS identificados nesses mesmos licenciandos por Ortiz e Magalhães Júnior (2019).

Os autores identificaram um núcleo central composto pelos seguintes elementos nos ingressantes do curso: "conhecimento geral"; comportamento docente"; "motivação pessoal" e "desejo de aprender” (ORTIZ; MAGALHÃES JÚNIOR, 2019). É importante lembrar que o núcleo de uma representação é composto pelos elementos que dão significado à mesma e a mantém estável (ABRIC, 2000).

Como os autores explicitam,

Esses elementos indicam uma perspectiva tradicionalista de ensino centrada no professor. Por um lado, há uma preocupação em refletir a respeito da própria prática, caracterizada pelo grupo semântico 'comportamento docente'; por outro lado, 'ser professor de Física' apresenta relação com dominar o conteúdo e possuir motivações pessoais (ORTIZ; MAGALHÃES JÚNIOR, 2019, p.13).

Já a periferia das RS é composta por elementos mais concretos e acessíveis, que concretizam, regulam e protegem o núcleo central (ABRIC, 2000). No caso desses ingressantes do curso de Física, a periferia mais externa identificada era composta por "relevância do conhecimento físico"; "interação com o aluno"; "afetividade com o aluno" e "atividades práticas".

Tanto o núcleo quanto a periferia se mostram de acordo com as concepções identificadas mediante a análise KVP, o que reforça a ideia de que as RS são uma construção tanto coletiva quanto individual (MOSCOVICI, 2015).

Nesse mesmo trabalho (ORTIZ; MAGALHÃES JÚNIOR, 2019), o núcleo central identificado nos concluintes era composto por "comportamento docente"; "conhecimento geral"; "motivação pessoal"; "afetividade com o aluno", enquanto a última periferia apresentava "desejo de aprender" e "externalidades e dificuldades".

A partir desses dados, os autores argumentam que "esse núcleo permanece centrado em uma perspectiva tradicional de ensino. Elementos relativos à contextualização, bem como aos conhecimentos pedagógicos não são identificados, salvo a afetividade (ORTIZ; MAGALHÃES JÚNIOR, 2019, p.14).

Esse resultado também se mostra de acordo com as concepções identificadas nesta pesquisa, onde percebemos que os concluintes se aproximam de conhecimentos, valores e práticas construtivistas, entretanto não abandonam concepções tradicionais evidenciadas entre os ingressantes. A afetividade, presente no núcleo central reforça a interpretação de que elementos construtivistas foram incorporados ao modelo tradicional (MASSABNI, 2007). Não deixa de ser uma alteração positiva, pois como Carvalho e Gil-Pérez (2011) alertam, a atenção aos aspectos afetivos e emocionais costumam escapar aos professores de Ciências.

Dessa maneira, além da compreensão da construção de uma representação social como coletiva e pessoal, também podemos desenvolver algumas inferências a respeito da objetivação e ancoragem nesse processo, como definidas por Moscovici (2015). As RS identificadas por Ortiz e Magalhães Júnior (2019) são corroboradas pelos conhecimentos, valores e práticas expostas pelos participantes dessa pesquisa. Existe uma relação entre esses elementos (CLÉMENT, 2006; 2010; 2018) que causa variações no conhecimento construído pelo sujeito.

Nesse sentido, apesar das RS desses sujeitos não apresentarem uma reorganização efetiva ao longo do curso, podemos identificar algumas alterações no significado dado aos elementos dessas representações. Quando falamos de conhecimento geral, por exemplo, isso implica nos conteúdos, mas também na compreensão do seu processo de construção, sua relação com tecnologia e sociedade e princípios da investigação científica (CACHAPUZ et al., 2001; GIL-PÉREZ et al., 2001; GARCÍACARMONA, 2009; CARVALHO; GIL-PÉREZ, 2011). 
Nesse contexto, as diferentes concepções dos concluintes e ingressantes a respeito da epistemologia da Ciência indicam que houve a incorporação de algumas das características essenciais do trabalho científico a sua objetivação de conhecimentos gerais, apesar das mesmas continuarem a compartilhar espaço com conceitos de senso comum (GIL-PÉREZ et al., 2001; CARVALHO; GILPÉREZ, 2011).

Também nos conhecimentos pedagógicos, pequenas mudanças foram notadas, entretanto, elas não foram suficientes para suplantar a aceitação dos modelos tradicionais de ensino, ou deslocá-los para uma posição mais significativa na hierarquia das RS.

O cenário apresentado por esses resultados indica que esse modelo de licenciatura, no qual os conhecimentos pedagógicos são propostos de forma complementar a uma formação científica geral não proporcionou mudanças significativas nas RS desses licenciandos, seja na hierarquia ou no significado dos elementos que a compõem.

Enfim, como Galvão, Magalhães Júnior e Carvalho (2015) especificaram, as concepções são construídas pelo sujeito a partir do mundo externo e as representações são um reflexo das propriedades do mundo externo para o sujeito. Nesse sentido, os KVP atuam oferecendo elementos de ancoragem e objetivação para a construção das RS, entretanto, quando essas RS são construídas, elas influenciam na leitura do mundo feita pelo sujeito, possibilitando a alteração de concepções. Assim se forma uma "via de mão dupla", onde os saberes vão sendo construídos coletiva e individualmente, interna e externamente.

\section{À GUISA DE UMA CONCLUSÃO}

Neste trabalho utilizamos 18 indicadores para identificar conhecimentos, valores e práticas de ingressantes e concluintes de um curso de licenciatura em Física a respeito da Física e seu ensino. Esses indicadores foram organizados em três dimensões: epistemologia da Ciência; ensino e aprendizagem; formação e atividade docente. O cruzamento de dados entre esses indicadores nos permitiu comparar quais concepções são possivelmente compartilhadas entre eles, podendo ser compreendidas como Representações Sociais.

Identificamos que os ingressantes do curso apresentam concepções, em uma perspectiva KVP, que se caracterizam principalmente pela interpretação empirista da Ciência e seu ensino, apesar de considerarem que o professor precisa saber mais que conceitos científicos para ensinar. Esse resultado reforça a existência de saberes e representações prévias, que podem influenciar no processo de formação caso sejam ignoradas.

No caso dos concluintes, foi possível identificar algumas mudanças em suas concepções, entretanto, as mesmas se deram sem apresentar grandes rompimentos com concepções dos ingressantes.

Os conhecimentos, valores e práticas identificados nesta pesquisa estão de acordo com representações sociais identificadas pelos autores nesse mesmo grupo de licenciandos, em um trabalho anterior. Isso facilita a compreensão das RS como um conhecimento construído dentro da sociedade, de forma coletiva e individual, por meio de mecanismos internos e externos ao sujeito. Além disso, a aproximação dos resultados aqui encontrados com investigação da estrutura das RS desenvolvido anteriormente, reforça a importância da triangulação de dados para melhor compreender o objeto de estudo das RS.

Compreendemos que as RS podem impactar tanto na formação quanto no trabalho docente. Nossos resultados indicam que um modelo de formação tradicional, em que os conhecimentos pedagógicos e didáticos são inseridos apenas posteriormente no curso, e não ao longo de todo ele, não proporciona um ambiente propício a mudanças profundas nessas representações. Isso não significa que o modelo de formação seja o único responsável por esse resultado, entretanto, o papel do contexto na construção de RS, e diferentes resultados de pesquisa que tratam da formação de professores de Ciências, nos levam a considerar que o mesmo apresenta relevância.

Enfim, surgem novas questões: um currículo que preze pela inserção de conhecimentos pedagógicos e didáticos ao longo de toda a formação pode propiciar um resultado diferente nesse processo? A prática docente e a formação continuada podem influenciar nas representações sociais sobre 
'ser professor de Física’ em professores atuantes na educação básica? Essas são perguntas que poderão orientar novas pesquisas, ampliando as discussões e contribuições da área de Representações Sociais ao Ensino de Física.

\section{REFERÊNCIAS}

ABRIC, J. C. A abordagem estrutural das Representações Sociais. In: MOREIRA, A. S. P.; OLIVEIRA, D. C. Estudos interdisciplinares de Representação Social. Gôiania: Cultura e qualidade, 2000. cap.1, p.27-39.

ALVES-MAZZOTTI, A. J. Representações Sociais: Aspectos teóricos e aplicações à Educação. Revista Múltiplas leituras, v.1, n.1, p.18-43. 2008. Disponível em: < https://www.metodista.br/revistas/revistas-metodista/index.php/ML/article/download/1169/1181>. Acesso: 29 jun 2020.

BECKER, F. A epistemologia do professor: o cotidiano da escola. 6ed. Petrópoles, Vozes. 1993.

BEHRENS, M. A. O paradigma Emergente e a prática pedagógica. 6ed. Petrópolis, Vozes. 2013.

CACHAPUZ, A. et al. A emergência da didáctica das ciências como campo específico do conhecimento. Revista Portuguesa de Educação, v.14, n.1, p.155-195. 2001. Disponível em: <http://www.redalyc.org/articulo.oa?id=37414108>. Acesso: 15 mai 2019.

CARVALHO, G. S.; CLÉMENT, P. Projecto "Educação em biologia, educação para saúde e educação ambiental para uma melhor cidadania": análise de manuais escolares e concepções de professores de 19 países (europeus, africanos e do próximo oriente). Revista Brasileira de Pesquisa em Educação para Ciência, v.7, n.2. 2007. Disponível em: https://periodicos.ufmg.br/index.php/rbpec/article/view/4036>. Acesso: 29 jun 2020.

CARVALHO, A. M. P.; GIL-PÉREZ, D. Formação de professores de Ciências: tendências e inovações. 10 ed. São Paulo, Cortez. 2011.

CLÉMENT, P. Science et idéologie: exemples em didactique et enépistemologie de labiologie. Actesducolloque Science - Médias - Société. p.53-69. 2004. Disponível em: <http://sciencesmedias.ens-lyon.fr/IMG/pdf/Clement.pdf>. Acesso: 29 jun 2020.

Conceptions, représentations sociales et modèle KVP. Skholê :cahiers de larecherche et dudéveloppement, Marseille, IUFM de l'académie d'Aix-Marseille. n. 16, p.55 - 70. 2010. Disponível em: $<$ https://hal.archives-ouvertes.fr/hal-01024972/document >. Acesso: 29 jun 2020.

Didactic Transpositionand the KVP Model: Conceptions as Interactions Between Scientific Knowledge, Valuesand Social Practices. Esera Summer School, IEC, Universidade Minho. p.9-18. 2006.

GALVÃO, C. B.; MAGALHÃES JÚNIOR, C. A. O.; CARVALHO, G. S. O uso de charges como instrumento para identificação de concepções individuais e representações sociais sobre dengue. Revista Gòndola, Enseñanza y Aprendizaje de las Ciencias, v.10, n.01, p.16-25. 2015. Disponível em: < http://repositorium.sdum.uminho.pt/bitstream/1822/41741/1/Dengue-Charges_RevGondola.pdf>. Acesso: 29 jun 2020.

GARCÍA-CARMONA, A. Invesigación em didáctica de la Física: tendencias actuales e incidencia en la formación del profesorado. Latin American Jornal Physics Educaticon, v.3, n.2, p.369-375. 2009. Disponível em: <https://idus.us.es/bitstream/handle/11441/16336/file_1.pdf;sequence=1\&isAllowed=y $>$. Acesso: 29 jun 2020.

GIERE, R. Explaining Science a Cognitive Approach. Chicago, The Universityof Chicago Press. 1988. 
GIL PÉREZ, D. et al. Para uma imagem não deformada do Trabalho Científico. Ciência \& Educação, v.7, n.2, p.125-153. 2001. Disponível em: < https://www.scielo.br/scielo.php?script=sci_arttext\&pid=S1516-73132001000200001 >. Acesso: 29 jun 2020.

GIL PÉREZ, D.; VILCHES, A. La formación del professorado de Ciencias de Secundaria y de Universidad. La necessária superacíon de algunos mitos bloqueadores. Educación en Química, v. 15, n. 1 p.43-58. 2004. Disponível em: <https://www.uv.es/vilches/documentos\%20enlazados/Edu.Quil04.pdf>. Acesso: 29 jun 2020.

HENZE, I.; VAN DRIEL, J. H.; VERLOOP, N. Development of Experienced Science Teachers' Pedagogical Content Knowledge of models of the Solar System and the Universe. International Journal of Science Education. v. 30, n.10, p.1321-1342. 2008.

HILGER, T. R.; MOREIRA., M. A. Uma revisão de Literatura sobre Trabalhos em Representações Sociais relacionados ao Ensino de Física. Revista Brasileira de Pesquisa em Educação em Ciências, v.16, n.1, $\quad$ p. $167-186, \quad 2016 . \quad$ Disponível em: < https://periodicos.ufmg.br/index.php/rbpec/article/view/4342 >. Acesso: 29 jun 2020.

JODELET, D. Representaciones sociales: contribucíon a un saber sociocultural sin fronteras. Revista Educação e Cultura Contemporânea, v.1, n.2, p.23-38. 2004. Disponível em: < http://periodicos.estacio.br/index.php/reeduc/article/view/2007/1021>. Acesso: 29 jun 2020.

MASSABNI, V. G. O construtivismo na prática de professores de ciências: realidade ou utopia? Ciência \& Cognição, v.10, p.104-114. 2007. Disponível em: $<$ http:// cienciasecognicao.org/pdf/v10/m346129.pdf>. Acesso: 29 jun 2020.

MAGAlHÃES JÚNIOR, C. A. O. Apresentação. In: MAGALHÃES JÚNIOR, C. A. O (org.). Representações Sociais, formação de professores e educação. Rio de Janeiro: Bonecker, 2018. p.2526.

MAGALHÃES JÚNIOR, C. A. O. et al. Concepções e Representações Sociais de professores de Ciências sobre sua formação: construção e validação de um questionário. Ensaio: Pesquisa em Educação em Ciências, v. 22, e12364, p. 1-35,2020. Disponível em: https://www.scielo.br/scielo.php?pid=S1983$21172020000100307 \&$ script$=$ sci_arttext. Último acesso em: 15 jun 2020.

MOSCOVICI, S. Representações Sociais: Investigações em Psicologia Social. Tradução: Pedrinho A. Guareschi. 11ºed. Petrópolis, RJ. Vozes. 2015.

ORTIZ, A. J.; MAGALHÃES JÚNIOR, C. A. O. Representações Sociais e Formação de professores: Reflexões. In: MAGALHÃES JÚNIOR, C. A. O (org.). Representações Sociais, formação de professores e educação. Rio de Janeiro: Bonecker, 2018. p.27-45.

Ser professor de Física: Representações Sociais na licenciatura. Ensaio: Pesquisa em Educação em Ciências, v. 21, e10462, p. 1-22, 2019. Disponível em: < https://www.scielo.br/pdf/epec/v21/1983-2117-epec-21-e10462.pdf>. Acesso: 29 jun 2020.

PARANHOS, R. et al. Uma introdução aos métodos mistos. Sociologias, v.18, n.42, p.384-411, 2016. Disponível em: < https://www.scielo.br/pdf/soc/v18n42/1517-4522-soc-18-42-00384.pdf>. Acesso: 29 jun 2020.

POOLE, M. Princípios e valores na Educação Científica. Tradução: Ana Andrade. Instituto Piaget, Lisboa, Portugal. 1995.

ROSENBERG, A. Philosophyof Science: A ContemporaryIntroduction. London, Routledge; 2000. 
SALAZAR, S. F. El Conocimiento Pedagógico del Contenido como Categoría de Estudio de la Formación Docente. Revista Electrónica Actualidades Investigativas Em Educacion, v. 5, n. 2, p.118. 2005. Disponível em: < https://revistas.ucr.ac.cr/index.php/aie/article/view/9139/17507>. Acesso: 29 jun 2020.

SHULMAN, L. S. Those who understand: knowledge growth in teaching. Educational Researcher, v. 15, n. 2, p. 4-14, 1986.

. Knowledgeand Teaching: Foundations of the New Reform. Harvard Educational Review, v. 57, n. 1, p. 1-21, 1987.

VASCONCELOS, M. L. Educação básica: a formação do professor, relação professor-aluno, planejamento, mídia e educação. São Paulo: Contexto. 2012.

ZAINKO, M. A. S. Políticas de formação de professores na universidade pública: uma análise de necessidades, entre o local e o global. Educar, n.37, p.113-127. 2010. Disponível em: $<$ https://www.scielo.br/scielo.php?script=sci_arttext\&pid=S0104-40602010000200008>. Acesso: 29 jun 2020.

Submetido: $14 / 03 / 2019$

Aprovado: 01/12/2019 